Historic, Archive Document

Do not assume content reflects current scientific knowledge, policies, or practices. 



\section{FALL 1918}

TRADE PRICE

LIST

FOR NURSERYMEN, DEALERS, FLORISTS AND

LANDSCAPE ARCHITECTS ONLY

Framingham Nurseries

(W B. WHITTIER \& CO.)

FRAMINGHAM, MASSACHUSETTS

(LOCATED TWENTY-ONE MILES WEST OF BOSTON)

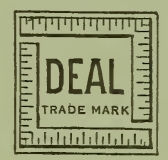

\begin{tabular}{|c|c|c|c|c|c|c|}
\hline Terms and Condi & & - & & 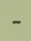 & & Page 2 \\
\hline Evergreen Trees & & - & - & & - & 3 \\
\hline Evergreen Shrubs & - & - & & - & & 9 \\
\hline Rhododendrons & & - & - & & & 10 \\
\hline Deciduous Trees & - & - & & - & & 12 \\
\hline Deciduous Shrubs & & - & - & & & 18 \\
\hline Roses & - & - & & - & & 27 \\
\hline Vines and Climbers & & - & - & & & 28 \\
\hline Fruit Trees & - & - & & - & & 29 \\
\hline Small Fruits & & - & - & & & 30 \\
\hline Motor Truck Trans & por & tation & - & & & 31 \\
\hline Our Location & - & - & & - & & 32 \\
\hline
\end{tabular}

LONG DISTANCE TELEPHONE, FRAMINGHAM 331

TELEGRAPHIC ADDRESS, FRAMINGHAM, MASS.

CABLE ADDRESS, FRAM BOSTON 


\section{QUALITY OF STOCK}

The stock offered in this list is strictly first-class, and, we believe, absolutely free from all injurious insects or diseases. We aim to keep our Nurseries clean, so that the stock is healthy and vigorous. We invite inspection. Visitors are always welcome. See back cover for location of Nurseries.

\section{SUBSTITUTION}

We never substitute one variety for another. Should the variety be exhausted, we at once notify the customer. In case the size ordered is exhausted, we send the next size thereto and charge accordingly, unless otherwise advised.

\section{THE PLANTING SEASON}

EVERGREENS can be successfully transplanted during August and September. DECIDUOUS TREES and SHRUBS can be safelyplanted any time after October 1st until freezing weather sets in.

\section{SHIPPING DIRECTIONS}

Parties ordering are requested to state explicitly the mode of conveyance by which they desire their stock forwarded.

When no route is designated, we exercise our judgment; but in no case do we assume any responsibility after packages are shipped, unless for our own mistakes. When losses occur by detention, claims should at once be made on the TRANSPORTATION COMPANY.

\section{CERTIFICATE OF INSPECTION}

Our nurseries are inspected every year by the State Nursery Inspectors, and a copy of the CERTIFICATE OF INSPECTION accompanies every shipment.

\section{CONDITIONS OF SALE}

First-The articles on the following list will be furnished at the annexed prices only when the quantity specified shall be taken. Five hundred will be furnished at the thousand rate; fifty at the hundred rate and five at the ten rate.

Second-We give no warranty, expressed or implied, as to quality, description, productiveness, or any other matter of any nursery stock that we sell. Nevertheless we shall, in the future, endeavor to live up to our reputation for square dealing as fully as we have in the past. No complaints will be considered that are not made within ten days after receipt of stock.

Third-The prices annexed do not include the boxes or bales. A charge is made for the actual cost of the boxes or the material used in baling. Boxes in which we have shipped stock and which are returned to us are generally so badly damaged in transit that we will allow credit for not over fifty per cent of the charge made for same. We make no charge for conveyance of shipment to the freight stations or express offices.

We reserve the right to change these prices at any time without notice.

Our terms are cash, unless by special agreement. We can ship by express C. O. D., when desired, with charges for collection added to the bill-provided 20 per cent of the amount of the order accoinpanies the same as a guarantee. Said guarantee will be required only from parties with whom we have no business acquaintance. All bills remaining unpaid December 1 st in fall, and June 1 st in spring, will be subject to sight draft without further notice. 


\section{HARDY EVERGREEN TREES}

The Evergreens we list are well developed and heavily rooted; they have been several times transplanted. We have a quantity of large specimens not listed; these can be selected at the nursery when prices will be given. A visit to our nurseries will pay you.

We always BALL and BURLAP our Evergreens at NO ADDITIONAL COST.

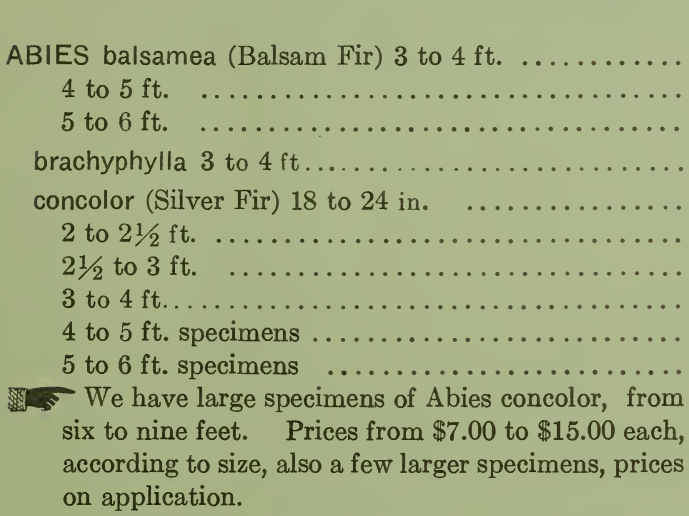

fraseri (Fraser's Fir) 6 to $7 \mathrm{ft} . \ldots \ldots \ldots \ldots \ldots \ldots . \ldots \ldots$

7 to $8 \mathrm{ft}$. specimens .................. 325

8 to $9 \mathrm{ft}$. specimens ................. 400

frazeri prostrata (new, distinctive) 15 to $18 \mathrm{in}$. spread 500

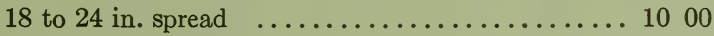

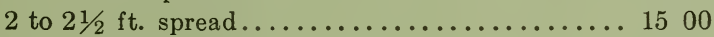

veitchii (Japanese Fir) 4 to $5 \mathrm{ft} . \ldots \ldots \ldots \ldots \ldots \ldots 300$

5 to $6 \mathrm{ft}$. ......................... 350

7 to $8 \mathrm{ft}$. specimens ..................... 500

8 to $9 \mathrm{ft}$. specimens ...................6 60

JUNIPERUS chinensis (Chinese Juniper) 2 to $2 \frac{1}{2} \mathrm{ft.} . \quad 125$

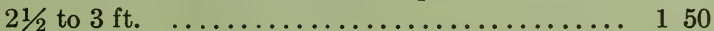

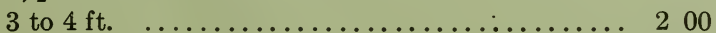

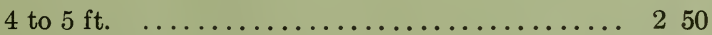

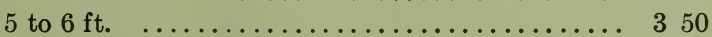

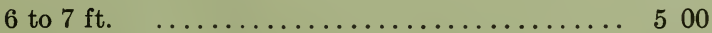

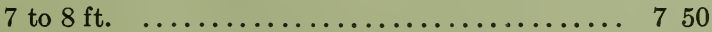

c. var. argentea 3 to $4 \mathrm{ft}$. ................... 200

4 to $5 \mathrm{ft}$. specimens ................... 400

5 to $6 \mathrm{ft}$. specimens ................ 500

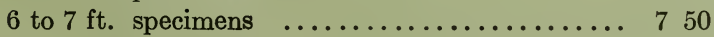

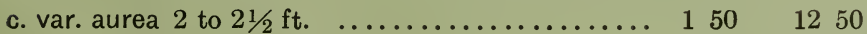

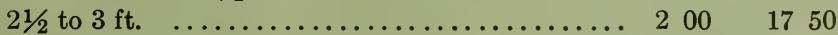

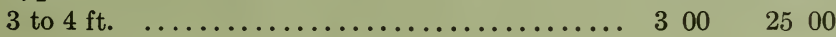

3000

3750

Per 100

1000

1250

1500

3500

1250

10000

15000

2250

3000

$27 \quad 50$

3250

1400

1500

2250

3000

4500

6500 
JUNIPERUS Continued communis (Dwarf Spreading or Prostrate Juniper)

15 to 18 in. spread . . . . . . . . . . . . . .

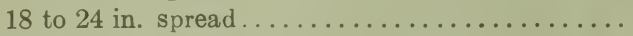

2 to $2 \frac{1}{2} \mathrm{ft}$. spread

$21 / 2$ to $3 \mathrm{ft}$. spread

3 to $4 \mathrm{ft}$. specimens

4 to $5 \mathrm{ft}$. specimens

com. var. aurea (Golden Spreading Juniper)

15 to 18 in. spread

18 to 24 in. spread

2 to $21 / 2 \mathrm{ft}$. spread specimens

com. var. cracovia 3 to $4 \mathrm{ft}$.

4 to $5 \mathrm{ft}$.

com. var. hibernica (Irish Juniper) 18 to 24 [n. .....

2 to $21 / 2 \mathrm{ft}$.

$21 / 2$ to $3 \mathrm{ft}$.

3 to $4 \mathrm{ft}$.

4 to $5 \mathrm{ft}$.

5 to $6 \mathrm{ft}$.

com. var. procumbens (Trailing Juniper)

18 to 24 in. spread

2 to $21 / 2 \mathrm{ft}$. spread

com. var. suecica (Swedish Juniper)

2 to $21 / 2 \mathrm{ft}$

$21 / 2$ to $3 \mathrm{ft}$.

3 to $4 \mathrm{ft}$.

4 to $5 \mathrm{ft}$. specimens

excelsa var. stricta (Greek Juniper)

2 to $2 \frac{1}{2} \mathrm{ft}$. specimens

$21 / 2$ to $3 \mathrm{ft}$. specimens

3 to $4 \mathrm{ft}$.

4 to $5 \mathrm{ft}$.

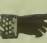

Juniper, grows very compact, perfectly hardy, and forms a perfect specimen where a dwarf evergreen is required.

japonica 18 to 24 in.................... 250

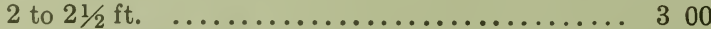

jap. var. aurea $2 \frac{1}{2}$ to $3 \mathrm{ft}$................... 250

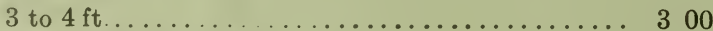

neaboriensis $21 / 2$ to $3 \mathrm{ft}$. $\ldots \ldots \ldots \ldots \ldots \ldots \ldots .250$

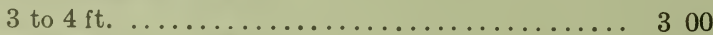

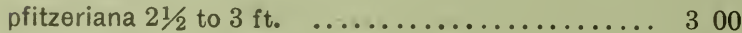

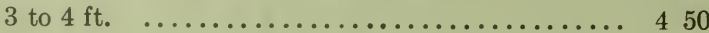

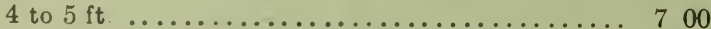

sabina (Savin Juniper) 15 to 18 in. spread........ 75

18 to 24 in. spread.................... 100

2 to $21 / 2 \mathrm{ft}$. spread...................... 150

$21 / 2$ to $3 \mathrm{ft}$. spread ...................... 200
Per 10 Per 100

$\begin{array}{rrrrr}5 & 50 & & 50 & 00 \\ 6 & 50 & 60 & 00 \\ 10 & 00 & 75 & 00 \\ 17 & 50 & & 135 & 00\end{array}$

650

1000

2250

2750

300

2500

$500 \quad 4000$

$6 \quad 50 \quad 60 \quad 00$

1000

1750

2500

15000

750

1000

500

700

6000

1000

1750

9000

15000

1250

10000

$1750 \quad 15000$

$2250 \quad 20000$

$\begin{array}{lll}25 & 00 & 22500\end{array}$

$27 \quad 50$

2250

2750

2250

4250

6000

650

5500

850

7500

1250

10000

1750

15000 


\begin{tabular}{|c|c|c|}
\hline UNIPERUS Continued & Each & Per \\
\hline virginiana (Red Cedar) 2 to $3 \mathrm{ft}$. & 100 & 8 \\
\hline$\ldots \ldots \ldots \ldots \ldots \ldots \ldots \ldots \ldots$ & 150 & 12 \\
\hline 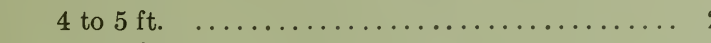 & 200 & $17^{\circ}$ \\
\hline 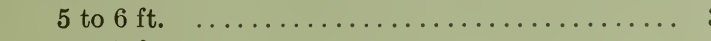 & 350 & 30 \\
\hline$\ldots \ldots \ldots \ldots \ldots \ldots \ldots \ldots \ldots \ldots$ & 500 & 45 \\
\hline 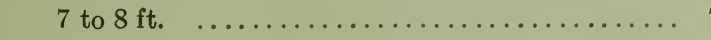 & 750 & 65 \\
\hline $\ldots \ldots \ldots \ldots \ldots \ldots \ldots \ldots \ldots \ldots \ldots \ldots \ldots \ldots$ & 1200 & 100 \\
\hline$\ldots \ldots \ldots \ldots \ldots \ldots \ldots 1$ & 150 & 25 \\
\hline $\mathrm{ft} . \ldots \ldots \ldots \ldots \ldots \ldots \ldots \ldots \ldots \ldots$ to 2 & 250 & \\
\hline legantissima 2 to $2 \frac{1}{2} \mathrm{ft} . \quad \ldots \ldots \ldots \ldots \ldots$ & & \\
\hline$\ldots \ldots \ldots \ldots \ldots \ldots \ldots \ldots \ldots$ & 250 & 22 \\
\hline${ }^{\prime} \ldots \ldots \ldots \ldots \ldots \ldots \ldots \ldots \ldots \ldots \ldots \ldots \ldots \ldots$ & 30 & \\
\hline & 400 & \\
\hline $5 \mathrm{t}$ & 500 & 45 \\
\hline ft. $\quad \ldots \ldots \ldots \ldots \ldots \ldots \ldots \ldots \ldots$ & 350 & 30 \\
\hline$\ldots \ldots \ldots \ldots \ldots \ldots \ldots$ & 500 & 45 \\
\hline specimens $\quad \ldots \ldots \ldots \ldots \ldots \ldots \ldots \ldots$ & 700 & 65 \\
\hline 7 to $8 \mathrm{ft}$. specimens $\ldots \ldots \ldots \ldots \ldots \ldots \ldots \ldots \ldots \ldots$ & 100 & 90 \\
\hline ens $\ldots \ldots \ldots \ldots \ldots \ldots \ldots \ldots \ldots \ldots \ldots \ldots$ & 1200 & 110 \\
\hline ens $\ldots \ldots \ldots \ldots \ldots \ldots \ldots \ldots \ldots \ldots \ldots$ & 1500 & 125 \\
\hline v. var. globosa 2 to $2 \frac{1}{2} \mathrm{ft} . \quad \ldots \ldots \ldots \ldots \ldots$ & 500 & \\
\hline White Spruce) 4 to $5 \mathrm{ft}$. & 20 & \\
\hline$\ldots \ldots \ldots \ldots \ldots \ldots \ldots$ & 250 & 22 \\
\hline 6 to & 350 & 32 \\
\hline & 500 & 45 \\
\hline $8 \mathrm{t}$ & 750 & 65 \\
\hline
\end{tabular}

Farger specimens: prices on application.

engelmanni 5 to $6 \mathrm{ft}$. specimens ........... 500

6 to $7 \mathrm{ft}$. specimens .................. 600

7 to $8 \mathrm{ft}$. specimens .................. 700

5000

8 to $9 \mathrm{ft}$. specimens ................... 800

6500

55000

9 to $10 \mathrm{ft}$. specimens .................... 900

7500

65000

10 to $12 \mathrm{ft}$. specimens ........... $\$ 1000$ to 1500

8500

75000

- Our Engelman Spruce are exceptionally fine specimens and have been frequently transplanted.

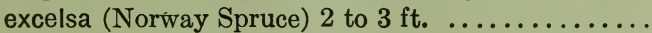

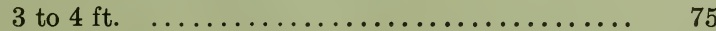

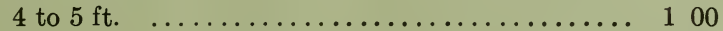

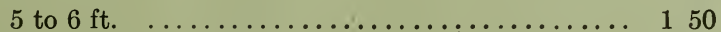

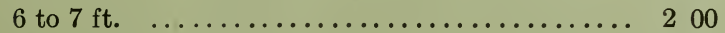

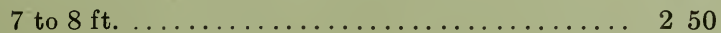

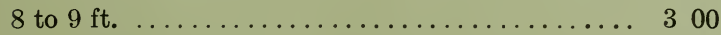

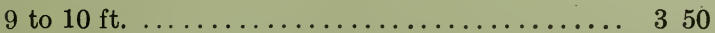

$2000 \quad 15000$

$2500 \quad 20000$

$3000 \quad 25000$

exc. var. gregoryana 18 to 24 in. $\ldots \ldots \ldots \ldots \ldots \ldots 750$

exc. var. maxwelli 2 to $21 / 2 \mathrm{ft}$. .............. 1200

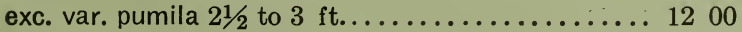

exc. var. pyramidalis 6 to $7 \mathrm{ft}$. $\ldots \ldots \ldots \ldots \ldots \ldots, 500$

orientalis gracilis 4 to $5 \mathrm{ft}$............... 400

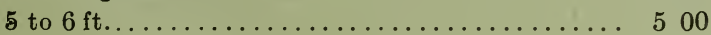


PICEA Continued

Each

Per 10

Per 100

pungens (Colorado Spruce, green form) 2 to $3 \mathrm{ft} . \ldots 100$

900

7500

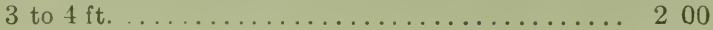

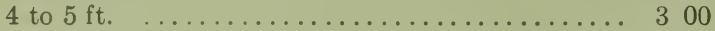

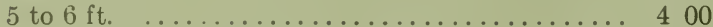

3500

6 to $7 \mathrm{ft}$. specimens ................. 500

4500

7 to $8 \mathrm{ft}$. specimens ................. 650

TLarger sizes: prices on application.

p. var. glauca (Colorado Blue Spruce) 2 to $3 \mathrm{ft}$..... 200

1600

14000

3 to $4 \mathrm{ft}$. specimens ................... 350

4 to $5 \mathrm{ft}$. specimens .................. 500

5 to $6 \mathrm{ft}$. specimens .................. 600

6 to $7 \mathrm{ft}$. specimens ................. 700

7 to $12 \mathrm{ft}$. specimens ............. \$10 00 to 2000

pungens var. kosteriana (Koster's Blue Spruce)

3 to $4 \mathrm{ft}$. specimens ................. 400

4 to $5 \mathrm{ft}$. specimens ................. 550

5 to $6 \mathrm{ft}$. specimens ................. 650

6 to $7 \mathrm{ft}$. specimens .................. 800

7 to $8 \mathrm{ft}$. specimens ................... 1250

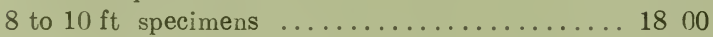

7500

10000

80000

15000

100000

PINUS austriaca (Austrian Pine) $2 \frac{1}{2}$ to $3 \mathrm{ft}$........ 125

1000

3 to $4 \mathrm{ft}$. specimens .................. 250

4 to $5 \mathrm{ft}$ specimens .................. 350

5 to $6 \mathrm{ft}$.

500

diviracata or banksiana (Jack Pine) 2 to $3 \mathrm{ft}$.

7 to $8 \mathrm{ft}$.

$75 \quad 600$

8 to $9 \mathrm{ft}$

$225 \quad 2000$

$300 \quad 2500$

montana (Mountain Pine) 2 to $21 / 2 \mathrm{ft} \ldots \ldots \ldots \ldots . . .250$

2250

$21 / 2$ to $3 \mathrm{ft}$.

300

2750

3 to $4 \mathrm{ft}$.

400

3500

m. var. mughus (Dwarf Mountain Pine)

12 to 15 in. spread .................... 100

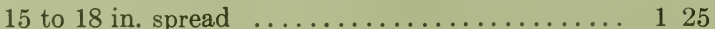

900

8000

18 to 24 in. spread

200

1100

9000

2 to $21 / 2 \mathrm{ft}$. spread

250

1750

15000

$21 / 2$ to $3 \mathrm{ft}$. spread

2250

20000

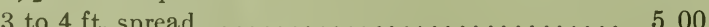

3000

25000

resinosa $2 \frac{1}{2}$ to $3 \mathrm{ft}$. ......................... 125

4000

3 to $4 \mathrm{ft}$.

1100

7000

4 to $5 \mathrm{ft}$.

150

1200

9000

strobus (White Pine) 18 to 24 in.

1500

2 to $21 / 2 \mathrm{ft}$.

500

$40 \quad 00$

$21 / 2$ to $3 \mathrm{ft}$.

3 to $4 \mathrm{ft}$.

100

750

6000

4 to 5

125

1000

7500

5 to $6 \mathrm{ft}$.

175

1500

10000

2250 
PSEUDOTSUGA taxifolia (Douglas Spruce)

Per 10 Per 100

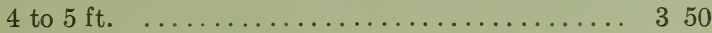

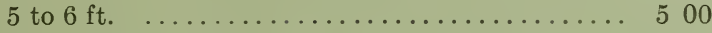

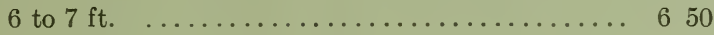

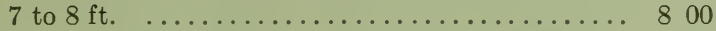

8 to $10 \mathrm{ft}$. specimens............. $\$ 1000$ to 1500

RETINISPORA filifera (Thread-branched Japanese Cypress)

18 to 24 in. . . . . . . . . . . . 125

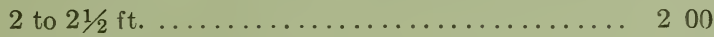

4 to $5 \mathrm{ft}$. specimens, very broad........... 600

5 to $6 \mathrm{ft}$. specimens, very broad........\$8 001200

filifera var. aurea 18 to 24 in. spread ......... 350

2 to $21 / 2 \mathrm{ft}$. spread .................. 500

4500

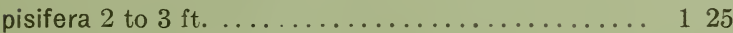

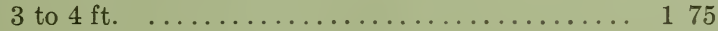

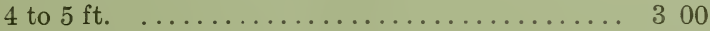

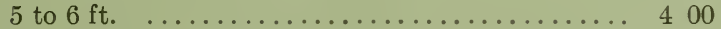

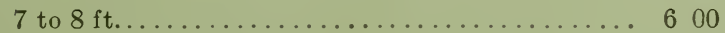

p. var. aurea 3 to $4 \mathrm{ft}$. ................ 200

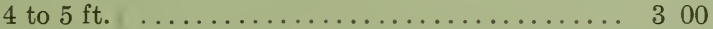

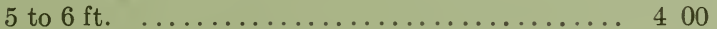

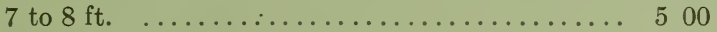

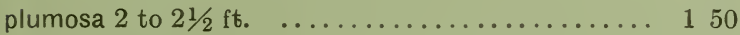

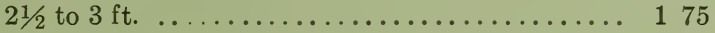

plumosa var. aurea 2 to $21 / 2 \mathrm{ft}$. sheared specimens .. 125

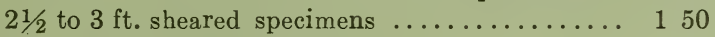

3 to $4 \mathrm{ft}$. sheared specimens............... 200

4 to $5 \mathrm{ft}$. sheared specimens.............. 250

1000

1500

2500

5 to $6 \mathrm{ft}$. sheared specimens.............. 300

1750

2500

6 to $7 \mathrm{ft}$. sheared specimens.............. 450

7 to $8 \mathrm{ft}$. sheared specimens .............. 600

8 to $9 \mathrm{ft}$. sheared specimens ............. 800

Special price will be given on large quantities of the above.

squarrosa veitchii 18 to 24 in. ................. $200 \quad 1750$

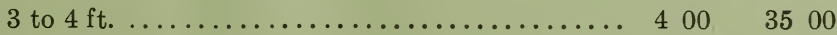

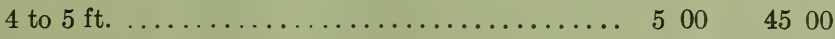

SCIADOPITYS verticillata 2 to $21 / 2 \mathrm{ft}$. specimens.... $400 \quad 3750$

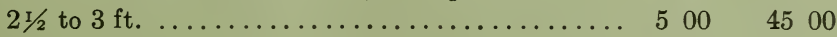

TAXUS (Yew)

canadensis (American Yew) 18 to 24 in. spread .... $125 \quad 1100$

2 to $2 \frac{1}{2} \mathrm{ft}$. spread .................... $200 \quad 1750$

cuspidata var. brevifolia 12 to 15 in. spread........ $175 \quad 1500 \quad 12500$

15 to 18 in. spread..................... $225 \quad 2000 \quad 17500$

18 to 24 in. spread................... $300 \quad 2750$

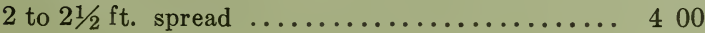


THUYA occidentalis (American Arbor Vitae)

Each Per 10

Per 100

2 to $3 \mathrm{ft}$.

$\begin{array}{lll}60 & 5 & 50\end{array}$

3 to $4 \mathrm{ft}$.

75

700

6000

4 to $5 \mathrm{ft}$.

125

6 to $7 \mathrm{ft}$.

200

9 to $10 \mathrm{ft}$. specimens

600

10 to $12 \mathrm{ft}$. specimens.

..\$7 50 to 1000

occ. var. aurea (Peabody's Golden Arbor Vitae)

2 to $3 \mathrm{ft}$.

3 to $4 \mathrm{ft}$.

10 to $12 \mathrm{ft}$.

350

occ. var. douglasi pyramidalis 3 to $4 \mathrm{ft}$.

150

4 to $5 \mathrm{ft}$.

250 .

5 to $6 \mathrm{ft}$.

350

6 to $7 \mathrm{ft}$.

500

7 to $8 \mathrm{ft}$.

750

1000

1750

7500

occ. var. globosa 15 to 18 in.

50

18 to 24 in.

75

2 to $21 / 2 \mathrm{ft}$. specimens

175

$21 / 2$ to $3 \mathrm{ft}$. specimens

250

occ. var. pyramidalis (Pyramidal Arbor Vitae)

$21 / 2$ to $3 \mathrm{ft}$.

125

1000

3 to $4 \mathrm{ft}$.

200

4 to $5 \mathrm{ft}$.

250

5 to $6 \mathrm{ft}$.

300

1750

2250

2750

15000

20000

occ. var. siberica (Siberian Arbor Vitae)

2 to $21 / 2 \mathrm{ft}$.

100

900

7500

$21 / 2$ to $3 \mathrm{ft}$.

125

3 to $4 \mathrm{ft}$.

200

4 to $5 \mathrm{ft}$.

300

1150

10000

1750

2500

15000

occ. var. vervaenana 3 to $4 \mathrm{ft} . \ldots \ldots \ldots \ldots \ldots \ldots 100$

750

4 to $5 \mathrm{ft}$. specimens

200

5 to $6 \mathrm{ft}$.

1750

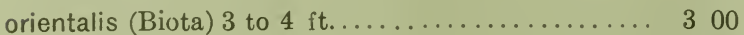

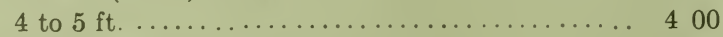

TSUGA canadensis (Hemlock) 2 to $21 / 2 \mathrm{ft} \ldots \ldots \ldots \ldots 125$

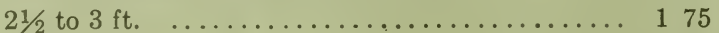

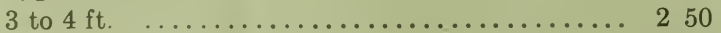

4 to $5 \mathrm{ft}$. bushy........................ 350

5 to $6 \mathrm{ft}$. bushy........................ 450

$1100 \quad 9000$

$1500 \quad 12500$

$2000 \quad 17500$

$3000 \quad 25000$

6 to $7 \mathrm{ft}$.

600

4000

32500

canadensis globosa (Globe Hemlock) slow growing;

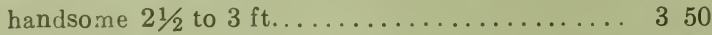

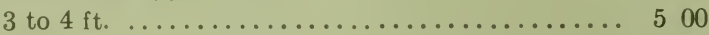

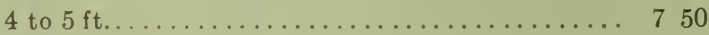




\section{EVERGREEN SHRUBS}

ANDROMEDA floribunda (See Pieris floribunda) Each

Per 10 Per 100

glaucaphylla 12 to 15 in.

75

650

6000

15 to 18 in.

100

900

8500

japonica (See Pieris japonica)

AZALEA japonica var. yodagawa (Double Pink)

2 to $2 \frac{1}{2} \mathrm{ft}$.

2252000

BERBERIS or Mahonia aquifolia 12 to $15 \mathrm{in}$.

20

150

1000

ilicifolia 18 to 24 in

35

2 to $21 / 2 \mathrm{ft}$.

BUXUS arborescens (Tree Box)

Bush form 18 to 24 in.

100

suffruticosa (Dwarf Box) 6 to 8 in

250

1800

COTONEASTER horizontalis 12 to 15 in. spread

EUONYMUS radicans 2 yrs.

rad. var. carrieri 2 yrs.

300

rad. var. vegeta (Round-leaved Euonymus) 2 yrs...

KALMIA latifolia (Mountain Laurel) 18 to 24 in. ....

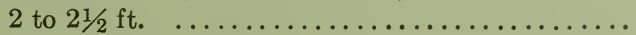

$21 / 2$ to $3 \mathrm{ft}$.

40

20

150

1000

$20 \quad 160$

1200

$20 \quad 150$

$20 \quad 160$

1200

$100 \quad 900$

$150 \quad 1400$

$250 \quad 2250$

LEUCOTHOE catesbaei

12 to 15 in.

50

450

PACHYSANDRA terminalis 2 yrs.

120

1000

3 yrs.

150

1200

PIERIS floribunda

15 to 18 in. broad

$150 \quad 1250$

18 to 24 in. broad

$\begin{array}{llll}2 & 00 & 17 & 50\end{array}$

japonica 15 to $18 \mathrm{in}$.

125

18 to 24 in.

150

YUCCA filamentosa 3 yrs. XX

20

1000

\section{WE INVITE INSPECTION}

We have a large stock of Evergreen Trees and Shrubs, Rhododendrons and other stock, and we believe it will pay you to visit the nurseries, where you can judge as to its quality and condition. If you require any large specimens it will be worth while to select them at the nurseries.

Directions for reaching our nurseries will be found on the last page. 


\section{RHODODENDRONS}

Our stock of Rhododendrons comprises the best of the Hybrids, which we have tested as to hardiness, the native Catawbiense and Maximum and also the dwarf Alpine varieties. We can furnish fine collected plants of the native Maximum by the car load sizes from two to six feet. Prices given on application.

RHODODENDRONS-Hardy Hybrid Varieties.

Abraham Lincoln (rosy red) 18 in. ........... 125

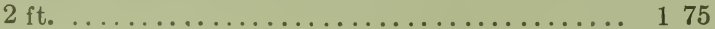

Album elegans (White large flower) $21 / 2 \mathrm{ft} . \ldots \ldots 300$

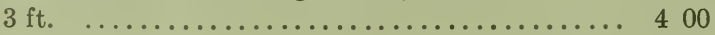

Album grandiflorum (white) $2 \frac{1}{2} \mathrm{ft} . \ldots \ldots \ldots \ldots 300$

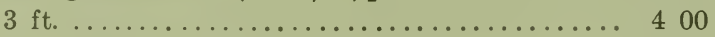

Atrosanguineum (crimson scarlet) 18 in. ....... 125

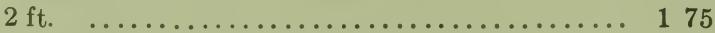

Boule de Neige (Pure white dwarf extremely hardy)

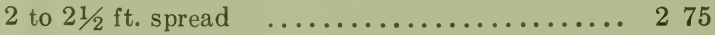

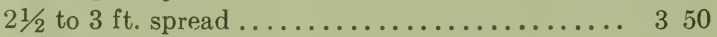

Caractacus (rich purplish crimson) $2 \mathrm{ft} . \ldots \ldots \ldots \ldots 175$

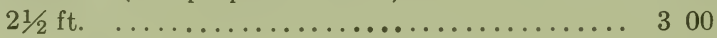

Catawbiense grandiflora alba $2 \mathrm{ft} . \quad \ldots \ldots \ldots \ldots \ldots 175$

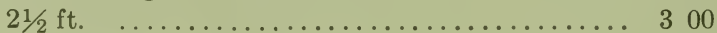

Charles Bagley (crimson) $2 \mathrm{ft} \ldots \ldots \ldots \ldots \ldots \ldots \ldots . \ldots \ldots$

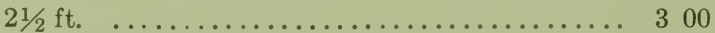

Charles Dickens (rich crimson) 18 in. ........ 125

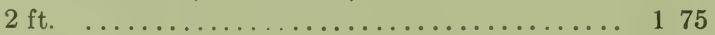

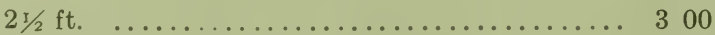

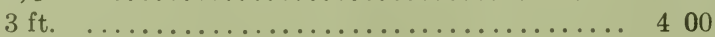

Delicatissimum (blush white) $21 / 2 \mathrm{ft} \ldots \ldots \ldots \ldots \ldots 300$

Edward S. Rand (bright scarlet) 18 in......... 125

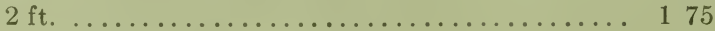

Everestianum (rosy lilac crimped) $2 \mathrm{ft} \ldots \ldots \ldots \ldots, 175$

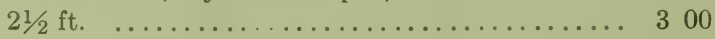

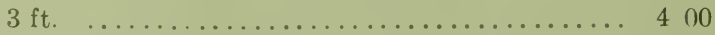

F. D. Godman (Crimson) $2 \mathrm{ft} . \quad \ldots \ldots \ldots \ldots \ldots \ldots 200$

Hanna Felix (bright scarlet) $21 / 2 \mathrm{ft} . \quad \ldots \ldots \ldots \ldots . \ldots 300$

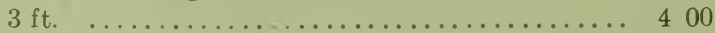

H. H. Hunnewell (Dark crimson) 18 in. ....... 125

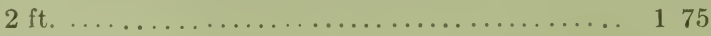

H. W. Sargent (Crimson) $2 \mathrm{ft} . \ldots \ldots \ldots \ldots \ldots \ldots$

Kettledrum (very lively crimson) $2 \mathrm{ft} . \ldots \ldots \ldots \ldots$ 
RHODODENDRONS Continued

Lady Armstrong (pale rose, spotted) $2 \mathrm{ft} . \ldots \ldots \ldots 175$

Lady Clermont (Dark red) $2 \mathrm{ft} \ldots \ldots \ldots \ldots \ldots \ldots \ldots \ldots$

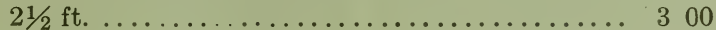

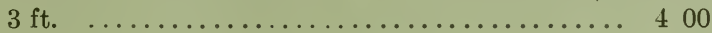

Mrs. Milner (rich crimson) 18 in. ........... 125

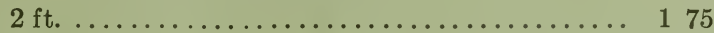

Parsons' Gloriosum (Large Blush) $2 \mathrm{ft} . \ldots \ldots \ldots \ldots .175$

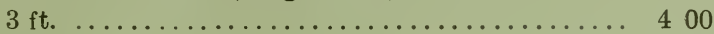

Parsons' grandiflorum (red) $3 \mathrm{ft} . \quad \ldots \ldots \ldots \ldots \ldots .400$

Pres. Lincoln (Rose) 3 to $4 \mathrm{ft}$. extra bushy ...... 750

Purpureum elegans $2 \mathrm{ft}$. ................. 175

Roseum elegans (fine rose) 18 in. ........... 125

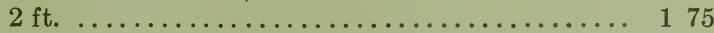

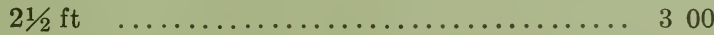

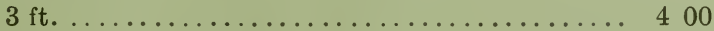

Roseum superbum $3 \mathrm{ft} . \quad \ldots \ldots \ldots \ldots \ldots \ldots \ldots . \ldots 400$

\section{NATIVE RHODODENDRON}

Carolinianum 15 in. ................... 100

18 in.............................. 150

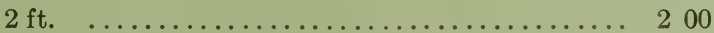

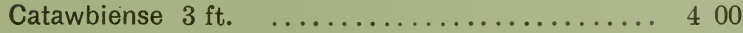

Catawbiense grandiforum (rosy lilac) $18 \mathrm{in.} \mathrm{.....} 150$

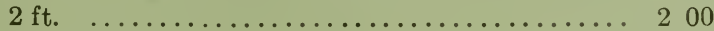

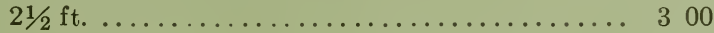

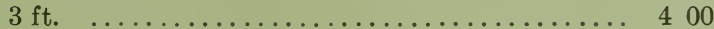

Maximum (hardy native) 18 in. ............ $100 \quad 900$

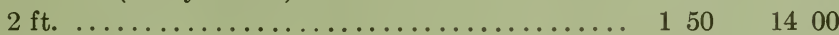

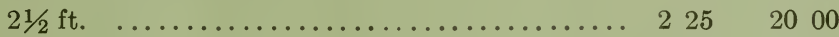

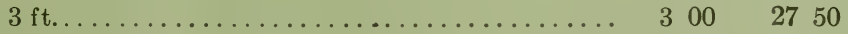

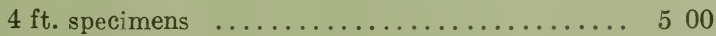

Extra large bushy specimens........\$7 50 to 1000
Per 10 Per 100 


\section{DECIDUOUS SHADE AND ORNAMENTAL TREES}

IMPORTANT-This list includes only such varieties of stock as we have now in our nurseries, in sizes and quantities offered. In filling orders we shall grade stock according to these specifications. Should orders be received for sizes not found in this list, or should any specified grade be exhausted, we will send the nearest size we have in stock at the time the order is received and charge accordingly; unless otherwise advised.

ACER dasycarpum (Silver-leaved Maple)

10 to $12 \mathrm{ft} .1 \frac{1}{4}$ to $1 \frac{1}{2}$ in. caliper ........... 60

Each Per 10 Per 100

10 to $12 \mathrm{ft} .1 \frac{1}{2}$ to $13 / 4$ in. ............... 75

75

12 to $14 \mathrm{ft} .13 / 4$ to 2 in. caliper ............ 125

14 to $16 \mathrm{ft} .2$ to $2 \frac{1}{2}$ in caliper ............ 150

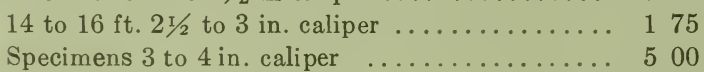

Specimens 5 to 6 in. caliper $\ldots \ldots \ldots \ldots \ldots \ldots 70$

dasy. var. wierii (Wier's Cut-leaved Maple)

10 to $12 \mathrm{ft} .11 / 4$ to $1 \frac{1 / 2}{2}$ in. caliper ........... 125

1000

12 to $14 \mathrm{ft} .13 / 4$ to 2 in. ............... 225

2000

Specimens 3 to 4 in. .........\$5 00 to 750

negundo var. argentea variegata 6 to $8 \mathrm{ft} \ldots \ldots \ldots 100$

n. var. aurea marginata 6 to $8 \mathrm{ft} . \ldots \ldots \ldots \ldots \ldots 100$

platanoides (Norway Maple) 8 to $10 \mathrm{ft}$.......... 60

10 to $12 \mathrm{ft} .1 \frac{1}{4}$ to $13 / 4$ in. caliper .......... 90

10 to $12 \mathrm{ft} .13 / 4$ to 2 in. caliper ............. 100

12 to $14 \mathrm{ft.} 1 \frac{1}{2}$ to 2 in. caliper ............. 125

12 to $14 \mathrm{ft} 2$ to $2 \frac{1}{2}$ in. caliper ............. 150

14 to $16 \mathrm{ft} .13 / 4$ to $2 \mathrm{in}$. caliper ........... 200

14 to $16 \mathrm{ft} .2$ to $21 / 2$ in. caliper............. 250

14 to $16 \mathrm{ft.} 2 \frac{1}{2}$ to $3 \mathrm{in}$. caliper ........... 400

16 to $18 \mathrm{ft.} 2$ to $21 / 2$ in. caliper ........... 400

16 to $18 \mathrm{ft} .3$ to 4 in. caliper ........... 500

18 to $20 \mathrm{ft.} 21 / 2$ to 3 in. caliper ........... 500

18 to $2 \mathrm{ft.} 3$ to 4 in. caliper .............. 600

20 to $24 \mathrm{ft} .3$ to 4 in. caliper ............. 700

$500 \quad 3500$

$600 \quad 5000$

$1000 \quad 7500$

$1250 \quad 10000$

1500

4500

Our Norway Maples are of extra fine quality.

Special prices will bə quoted on carload shipments.

p. var. schwedleri (Purple leaved)

12 to $14 \mathrm{ft} .13 / 4$ to 2 in. caliper ............ 200

14 to 16 it. 2 to $21 / 2$ in. caliper ............ 300

18 to $20 \mathrm{ft} .2 \frac{1}{2}$ to $3 \mathrm{in.}$ caliper ........... 400

Specimens 4 to 6 in. ........... \$5 00 to 1250

pennsylvanicum (Striped Maple) 5 to $6 \mathrm{ft}$........ 100

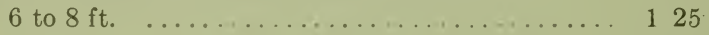

800

$550 \quad 4500$

$750 \quad 6500$

$850 \quad 7500$

$1000 \quad 8500$

$1250 \quad 10000$

$1500 \quad 12500$

$22 \quad 50 \quad 18500$

$\begin{array}{llll}35 & 00 & 275 & 00\end{array}$

$3500 \quad 27500$

$\begin{array}{llll}4500 & 37500\end{array}$

$\begin{array}{llll}4500 & 375 & 00\end{array}$

$5500 \quad 50000$

6500 
ACER Continued

rubrum (Red Maple) 10 to $12 \mathrm{ft}$.

12 to $14 \mathrm{ft}$.

saccharum (Sugar Maple)

10 to $12 \mathrm{ft} .1 \frac{1}{4}$ to $11 / 2$ in. caliper ........... 100

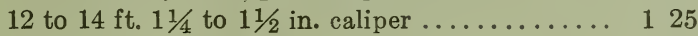

12 to $14 \mathrm{ft} .11 / 2$ to $13 / 4$ in. caliper. ........... 150

14 to $16 \mathrm{ft} .1 \frac{1}{2}$ to $13 / 4$ in. caliper ........... 175

14 to $16 \mathrm{ft.} 13 / 4$ to 2 in. caliper ............. 200

14 to $16 \mathrm{ft} .2$ to $21 / 2$ in. caliper ............ 250

tataricum var. ginnala 4 to $5 \mathrm{ft}$. ............. 60

5 to $6 \mathrm{ft}$.

AESCULUS

hippocastanum (Horse Chestnut) 8 to $10 \mathrm{ft} . \ldots \ldots 125$

10 to $12 \mathrm{ft.} 2$ to $21 / 2$ in. caliper ............. 150

12 to $14 \mathrm{ft} .21 / 2$ to 3 in. extra specimens ....... 300

12 to $14 \mathrm{ft} .3$ to 4 in. caliper extra specimens .... 450

4 to 5 in. caliper extra specimens .....\$5 00 to 1000 hip. var. alba plena (Double white)

12 to $14 \mathrm{ft} .21 / 2$ to 3 in caliper ............ 300

12 to $14 \mathrm{ft} .3$ to $4 \mathrm{in}$. caliper specimens.. $\$ 500$ to 750

pavia var. carnea 8 to $10 \mathrm{ft}$. ................ 125

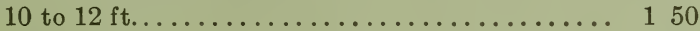

ARALIA maximowiczii (Acanthopanax) 8 to $10 \mathrm{ft}$. .. 150

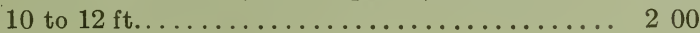

spinosa (Hercules Club) 3 to $4 \mathrm{ft} . \ldots \ldots \ldots \ldots \ldots . \quad 50$

BETULA alba (European White Birch)

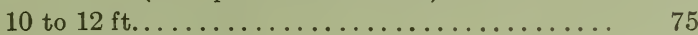

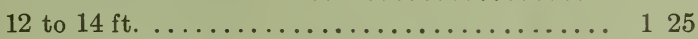

alba var. laciniata (Cat-leaved Birch) 8 to $10 \mathrm{ft}$. . 150

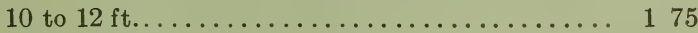

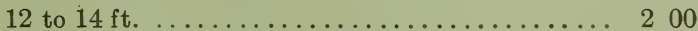

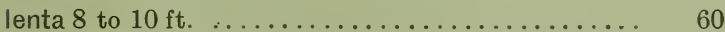

10 to $12 \mathrm{ft}$. .......................... 85

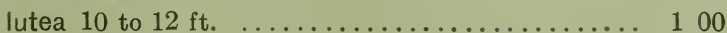

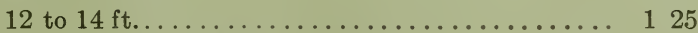

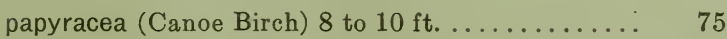

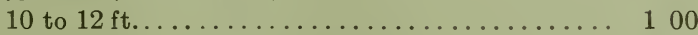

12 to $14 \mathrm{ft} .11 / 2$ to 2 in. caliper ........... 125

CARPINUS betulus 5 to $6 \mathrm{ft}$.

6 to $8 \mathrm{ft}$.

CATALPA speciosa 10 to $12 \mathrm{ft}$

12 to $14 \mathrm{ft}$.

CERASUS avium fl. pl. alba 5 to $6 \mathrm{ft}$

6 to $7 \mathrm{ft}$.

japonica alba fl. pl. 6 to $7 \mathrm{ft}$

var. rosea fl. pl. 6 to $7 \mathrm{ft}$.

var. hisakura (Double pink) 6 to $7 \mathrm{ft}$

pumila japonica multiflora 5 to $6 \mathrm{ft}$. stems .
Per 10 Per 100

1250

800

7000

$1000 \quad 8000$

$1250 \quad 9000$

$1500 \quad 12000$

$1700 \quad 14000$

$2250 \quad 20000$

$500 \quad 4000$

$600 \quad 5000$

1000

2500

4000

2500

1000

1250

650

5500

1000

1250

1500

1750

500

700

800

1000

650

750

1000

$\begin{array}{ll}60 & 00\end{array}$

400

600

550

$\begin{array}{lll}60 & 5 & 50 \\ 90 & 8 & 00\end{array}$

4500

250

300

250

250

300

2500

4500 
CERCIS canadensis (Judas Tree) 3 to $4 \mathrm{ft} . \ldots \ldots \ldots, \quad 40$

Per 10 Per 100

4 to $5 \mathrm{ft}$.

50

350

450

CHIONANTHUS virginica (White Fringe) 3 to $4 \mathrm{ft}$. 50

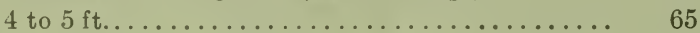

CLADRASTIS tinctoria (Virgilia Lutea) 6 to $7 \mathrm{ft} \ldots \ldots 125$

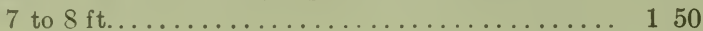

CORNUS florida 2 to $3 \mathrm{ft} . \ldots \ldots \ldots \ldots \ldots \ldots . .60$

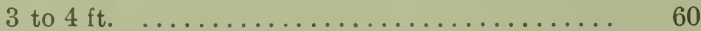

florida rubra 2 to $3 \mathrm{ft} \ldots \ldots \ldots \ldots \ldots \ldots \ldots \ldots \ldots$

CRATAEGUS azarolus var. carriere 6 to $8 \mathrm{ft} . \ldots \ldots 100$

coccinea 4 to $5 \mathrm{ft}$..................... 50

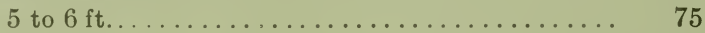

6 to $8 \mathrm{ft}$.......................... 100

cordata (Washington Thorn) 4 to $5 \mathrm{ft}$......... 50

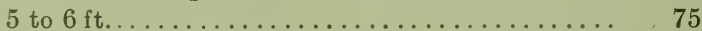

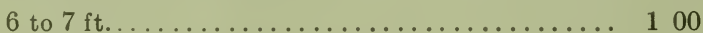

crus-galli (Cockspur Thorn) 3 to $4 \mathrm{ft}$. ....... 50

4 to $5 \mathrm{ft} \ldots \ldots \ldots \ldots \ldots \ldots \ldots \ldots \ldots \ldots \ldots \ldots \ldots \ldots$

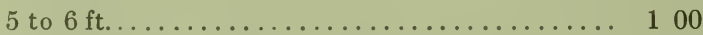

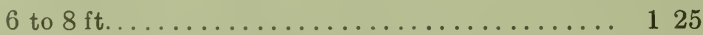

oxyacantha (Common Hawthorn) 6 to $7 \mathrm{ft} . \ldots \ldots$

75

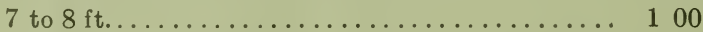

oxy. var. flore plena alba (Double white thorn)

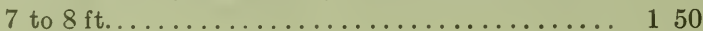

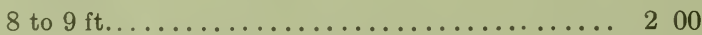

oxy. var. flore plena pauli (Paul's Double Scarlet Thorn)

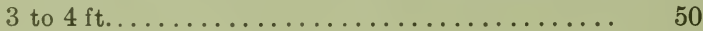

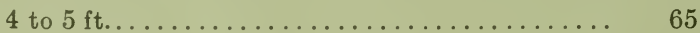

900

400

550

4500

800

6000

400

600

850

400

$30 \quad 00$

500

800

6000

1000

650

$70 \quad 00$

FAGUS grandifolia (American Beech)

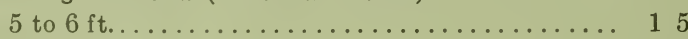

150

850

$12 \quad 50$

1750

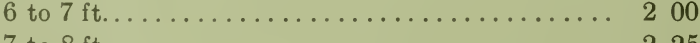

225

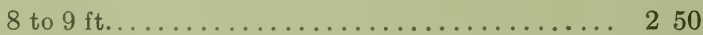

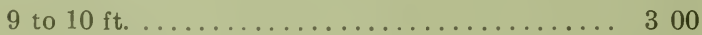

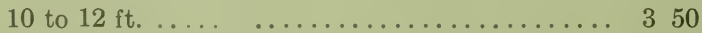

450

600

sylvatica (Eup. Beech) 4 to $5 \mathrm{ft} . \quad \ldots \ldots \ldots \ldots \ldots .60$

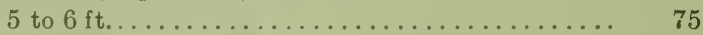

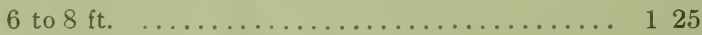

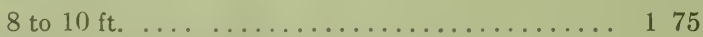

sylvatica var. asplenifolia (Tree Form)

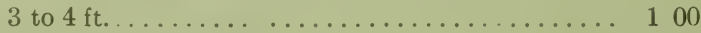

syl. var. pendula 8 to $9 \mathrm{ft} . \ldots \ldots \ldots \ldots \ldots \ldots . \ldots \ldots$

syl. var. purpurea (Purple-leaved Beech)

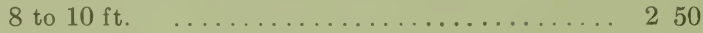

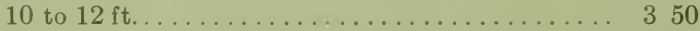

syl. var. purpurea pendula (Purple leaved weeping Beech)

6 to $8 \mathrm{ft}$. specimens ................. 500

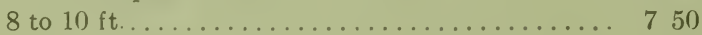

$1250 \quad 100 \quad 00$

$1500 \quad 12500$

$20 \quad 00 \quad 150 \quad 00$

$2250 \cdot 17500$

2500

3000

.

\section{5}


FAGUS Continued

Each

syl. var. riversii (Rivers' Purple Beech) 6 to $7 \mathrm{ft}$.

7 to $8 \mathrm{ft}$.

8 to $9 \mathrm{ft}$. specimens

9 to $10 \mathrm{ft}$. specimens

$\ldots \ldots \ldots \ldots \ldots \$ 50$ to 1000

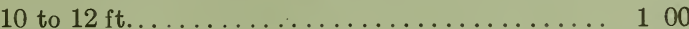

GINKGO biloba (Maidenhair Tree) 6 to $8 \mathrm{ft} \ldots \ldots \ldots 125$

JUGLANS nigra (Black Walnut) 5 to $6 \mathrm{ft}$......... 60

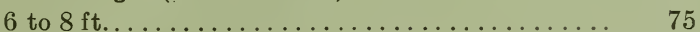

KOELREUTERIA paniculata (Varnish Tree) 3 to $4 \mathrm{ft} . \quad 60$

4 to $5 \mathrm{ft} . \ldots \ldots \ldots \ldots \ldots$. ................. 75

LABURNUM vulgare 8 to $10 \mathrm{ft} . \ldots \ldots \ldots \ldots \ldots \ldots$

LARIX europaea (European Larch) 5 to $6 \mathrm{ft}$. ..... 75

MAGNOLIA soulangeana 5 to $6 \mathrm{ft} \ldots \ldots \ldots \ldots \ldots 300$

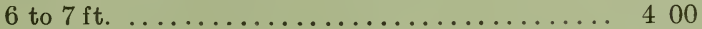

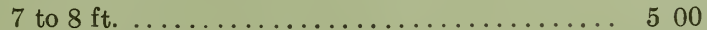

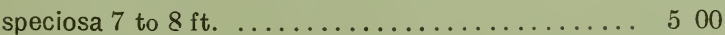

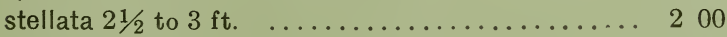

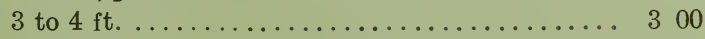

MALUS (Pyrus) angustifolia (Bechtel's Dbl. Flg. Crab)

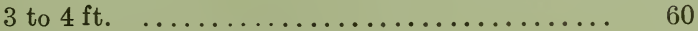

floribunda (Flowering Crab) 4 to $5 \mathrm{ft} \ldots \ldots \ldots \ldots .75$

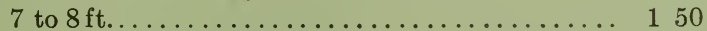

flor. var. atrosanguinea 5 to $6 \mathrm{ft}$............ 100

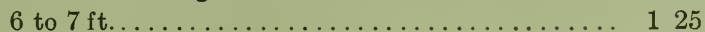

flor. var. scheideckeri 5 to $6 \mathrm{ft} \ldots \ldots \ldots \ldots \ldots \ldots, 100$

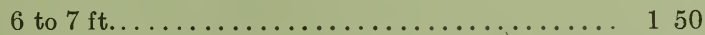

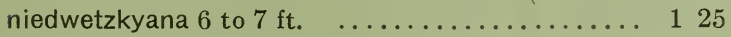

parkmanni 5 to $6 \mathrm{ft} . \ldots \ldots \ldots \ldots \ldots \ldots \ldots \ldots$

spectabilis 5 to $6 \mathrm{ft}$.................. 100

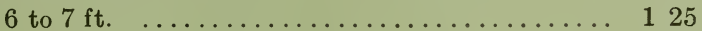

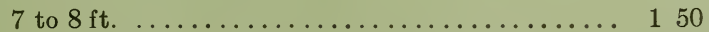

spectabilis alba. flora plena 7 to $8 \mathrm{ft}$. specimens.... 150

POPULUS alba 6 to $8 \mathrm{ft} . \ldots \ldots \ldots \ldots \ldots \ldots . \ldots$

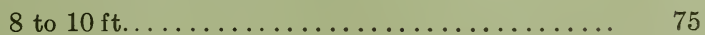

alba var. bolleana 10 to $12 \mathrm{ft} \ldots \ldots \ldots \ldots \ldots \ldots . \ldots \ldots$

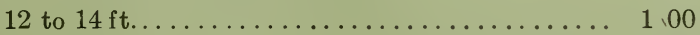

alba var. canescens 10 to $12 \mathrm{ft}, \ldots \ldots \ldots \ldots \ldots$. 75

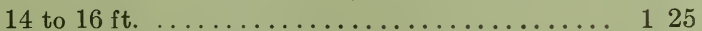

deltoides (Carolina Poplar) 10 to $12 \mathrm{ft}$........ 60

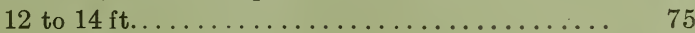

fastigiata (Lombardy Poplar) 6 to $8 \mathrm{ft}$........ 30

8 to $10 \mathrm{ft}$.

10 to $12 \mathrm{ft} .11 / 4$ to $1 \frac{1}{2} \mathrm{in}$.

12 to $14 \mathrm{ft} .11 / 2$ to 2 in.

100

14 to $16 \mathrm{ft} .2$ to $21 / 2 \mathrm{in}$.

150

simoni 6 to $8 \mathrm{ft}$.

Per 100

2750

$37 \quad 50$

4500

650

500

600

500

4000

650

5000

1200

650

1000

750

1000

1250

500

650

600

750

600

8 to $10 \mathrm{ft}$.

60

10 to $12 \mathrm{ft}$ 
PRUNUS pissardi (Purple-leaved Plum) 4 to $5 \mathrm{ft}$. . . $\quad \begin{array}{r}\text { Each } \\ \text { Pan }\end{array}$

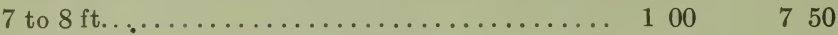

PTELEA trifoliata (Hop Tree) 5 to $6 \mathrm{ft} . \ldots \ldots \ldots \ldots 30 \quad 250$

PYRUS (flg. Crab) See Malus

QUERCUS alba (White Oak) 6 to $8 \mathrm{ft} . \ldots \ldots \ldots 200$

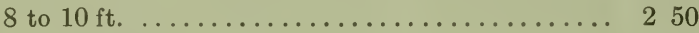

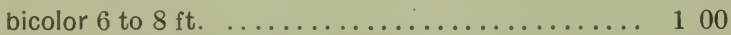

coccinea (Scarlet Oak) 8 to $10 \mathrm{ft} . \ldots \ldots \ldots \ldots \ldots 200 \quad 1750$

palustris (Pin Oak) 6 to $8 \mathrm{ft} . \ldots \ldots \ldots \ldots \ldots \ldots 100 \quad 900$

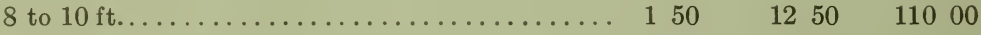

10 to $12 \mathrm{ft} .1 \frac{1}{2}$ to 2 in. ................ $200 \quad 1750$

10 to $12 \mathrm{ft} .2$ to $21 / 2$ in. ............... $300 \quad 2750 \quad 25000$

12 to $14 \mathrm{ft} .2 \frac{1}{2}$ to 3 in. ................ $350 \quad 3250$

robur (English Oak) 6 to $8 \mathrm{ft} . \ldots \ldots \ldots \ldots \ldots \ldots 125 \quad 1100$

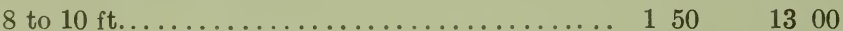

rubra (Red Oak) 6 to $8 \mathrm{ft} . \ldots \ldots \ldots \ldots \ldots \ldots \ldots 100 \quad 80 \ldots$

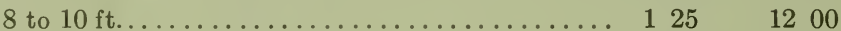

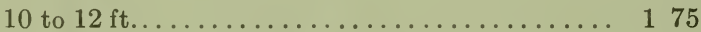

12 to $14 \mathrm{ft} .2$ to 3 in. cal. specimens......... 400

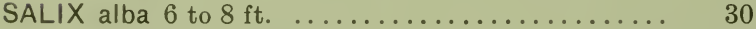

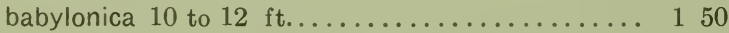

pentandra (Laurel-leaved Willow) 6 to $8 \mathrm{ft} . \ldots \ldots . \quad 50$

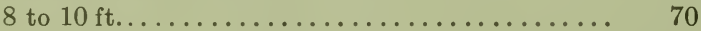

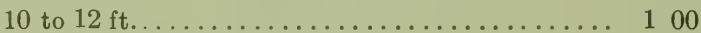

rosmarinifolia 3 to $4 \mathrm{ft} \ldots \ldots \ldots \ldots \ldots \ldots \ldots \ldots \ldots \ldots \ldots \ldots \ldots \ldots \ldots \ldots \ldots \ldots \ldots \ldots$
vitellina aurea 5 to $6 \mathrm{ft} \ldots \ldots \ldots \ldots \ldots \ldots$

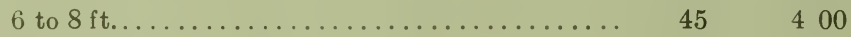

SOPHORA japonica 4 to $5 \mathrm{ft} . \ldots \ldots \ldots \ldots \ldots \ldots \ldots$

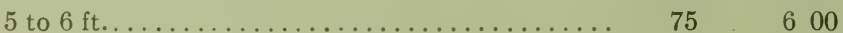

SORBUS aucuparia (European Mountain Ash)

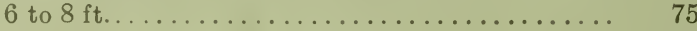

600

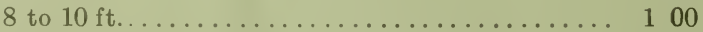

850

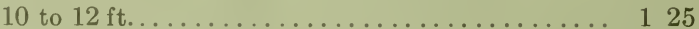

quercifolia (Oak-leaved Mountain Ash)

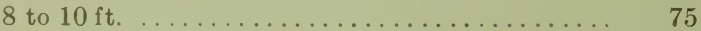

SYRINGA japonica (Japanese Tree Lilac) 5 to $6 \mathrm{ft} . \quad 60 \quad 600 \quad 500 \quad 3500$

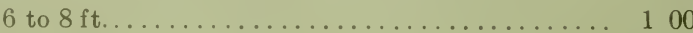

$750 \quad 5000$

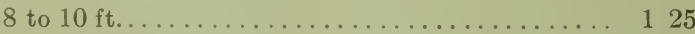

1000

TAXODIUM distichum 6 to $8 \mathrm{ft} \ldots \ldots \ldots \ldots \ldots \ldots 250 \quad 2 \ldots$ 


\section{}

TILIA americana (American Linden) 8 to $10 \mathrm{ft.....} 125$

Each
125

Per 10 Per 100

10 to $12 \mathrm{ft} .1 \frac{1}{2}$ to 2 in. caliper ............ 175

1000

12 to $14 \mathrm{ft.} 21 / 2$ to 3 in. caliper ............ 300

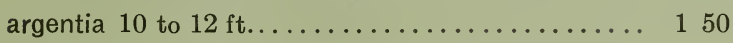

1500

dasystyla (Crimean Linden) 14 to $16 \mathrm{ft} .2 \frac{1}{2}$ to $3 \mathrm{in.} 300$

3 to 4 in. specimens ............\$4 00 to 1000

europaea (European Linden) 8 to $10 \mathrm{ft}$......... 100

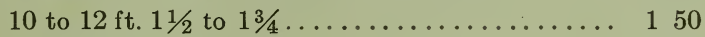

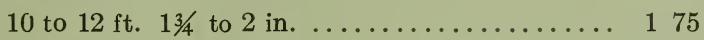

12 to $14 \mathrm{ft} .2$ to $2 \frac{1}{2}$ in. ............... 200

1250

2500

12 to $14 \mathrm{ft} .21 / 2$ to 3 in. ................ 250

14 to $16 \mathrm{ft} .2$ to $2 \frac{1}{2}$ in. ............... 300

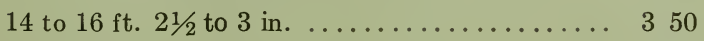

14 to $16 \mathrm{ft} .3$ to $4 \mathrm{in}$. specimens .......... 500

$850 \quad 7500$

$1250 \quad 10000$

$1500 \quad 12500$

$1750 \quad 15000$

e. var. parvifolia (Small Leaved Linden) 8 to $10 \mathrm{ft}$. 100

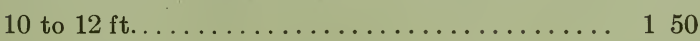

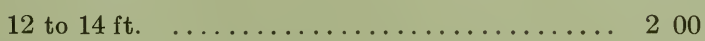

platyphylos (Large Leaf Linden)

12 to $14 \mathrm{ft} .2 \frac{1}{2}$ to 3 in. caliper ............ 200

3000

4500

850

7500

$1250 \quad 11000$

1750

Our. Lindens are especially fine, have straight, well-developed tops, and have been several times transplanted.

ULMUS americana (American Elm) 8 to $10 \mathrm{ft} \ldots \ldots .75$

10 to $12 \mathrm{ft.} 1 \frac{1}{2}$ to 2 in. ................ 100

$600 \quad 5000$

12 to $14 \mathrm{ft} .2$ to $2 \frac{1}{2}$ in. ................. 175

850

7500

3 to 4 in. specimens ............... 350

1500

campestris (English Elm)

16 to $18 \mathrm{ft} .21 / 2$ to 3 in. ................ $250 \quad 2000$

3 to 4 in. specimens................. $350 \quad 3250$

4 to 6 in. specimens............\$5 00 to 1000

var. wheatleyii 12 to $14 \mathrm{ft.} 2$ to $2 \frac{1}{2}$ in. ........ $150 \quad 1250$

12 to $14 \mathrm{ft} .2 \frac{1}{2}$ to 3 in. ................. $175 \quad 1500$

montana (Scotch or Wych Elm) 8 to $10 \mathrm{ft} \ldots \ldots \ldots 100 \quad 850$

7000

10 to $12 \mathrm{ft} .11 / 2$ to $2 \mathrm{in}$.

125

1000

8500

12 to $14 \mathrm{ft} .2$ to $21 / 2$ in.

175

1500

14 to $16 \mathrm{ft} .2 \frac{1}{2}$ to 3 in. ................ 250

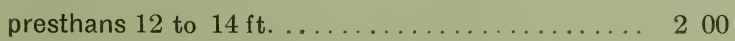




\section{DECIDUOUS FLOWERING AND ORNAMENTAL SHRUBS}

Our shrubs are grown with plenty of space in the nursery rows to insure good, vigorous growth, and they lift with strong roots; they are healthy and make quick development after planting.

ACANTHOPANAX sessiliflorus 2 to $3 \mathrm{ft} \ldots \ldots \ldots . .20$

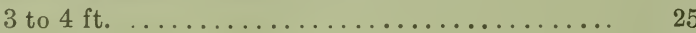

AMELANCHIER canadensis 2 to $3 \mathrm{ft} . \ldots \ldots \ldots \ldots$.

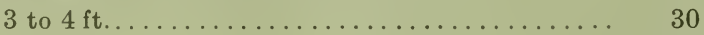

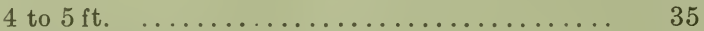

AMORPHA canescens 18 to 24 in............. 25

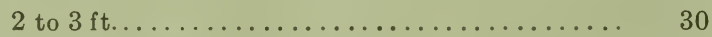

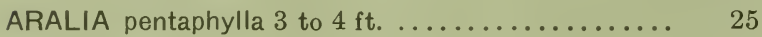

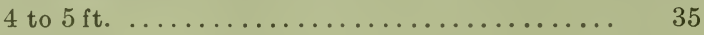

spinosa (See under trees).

ARONIA arbutifolia 2 to $3 \mathrm{ft} \ldots \ldots \ldots \ldots \ldots \ldots \ldots . \ldots \ldots$

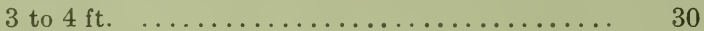

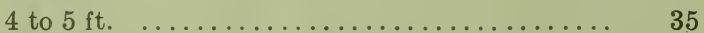

AZALEA arborescens 15 to 18 in. bushy plants .... 75

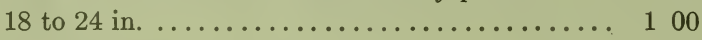

2 to $21 / 2 \mathrm{ft}$. very bushy................. 150

lutea (calendulacea) 18 to 24 in. .............. 125

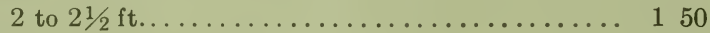

canadensis (Rhodora) 15 to 18 in. ............ 60

mollis 15 to 18 in. well branched and budded..... 50

18 to 24 in........................ 100

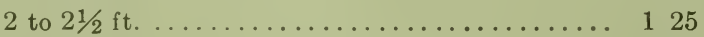

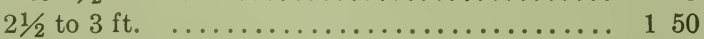

Per 10 Per 100

$150 \quad 1200$

$200 \quad 1500$

$200 \quad 1500$

250

$200 \quad 1500$

$250 \quad 2000$

$200 \quad 1500$

$250 \quad 1800$

udiflora 18 to 24 in..................... 100

$200 \quad 1500$

$250 \quad 2000$

$300 \quad 2500$

650 .

900

1250

10000

$1000 \quad 8000$

$1250 \quad 10000$

$500 \quad 4000$

$450 \quad 4000$

$800 \quad 6000$

$1000 \quad 8000$

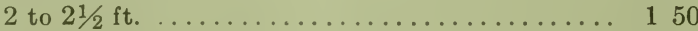

1250

900

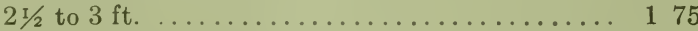

1250

1500

pontica (Ghent Azalea)

18 to 24 in. stocky, well-budded plants ....... $125 \quad 1000$

2 to $21 / 2 \mathrm{ft}$.

175

1500

Varieties: Cardinal, bright red; Bouquet de flora, pink; Davesii, white; Nancy

Waterer, yellow; Pallas, dark red; Unique, deep yellow; Wilhelm III, orange. vaseyi 15 to 18 in.

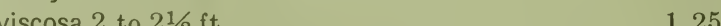

$21 / 2$ to $3 \mathrm{ft}$.

125

175

1000

8000

3 to $4 \mathrm{ft}$. . .

200

1500

12500

1750

15000

NOTE - All our Azalaes are lifted with a ball and burlapped at no extra cost.

BACCHARIS halimifolia 3 to $4 \mathrm{ft}$............ 30 
BERBERIS neuberti $2 \frac{1}{2}$ to $3 \mathrm{ft} . \ldots \ldots \ldots \ldots \ldots$

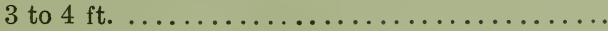

sieboldi 2 to $21 / 2 \mathrm{ft}$.

$21 / 2$ to $3 \mathrm{ft}$

3 to $4 \mathrm{ft}$.

thunbergii (Japanese Barberry)

12 to 15 in. bushy, $\$ 5000$ per thousand .......

15 to 18 in. bushy, $\$ 6000$ per thousand .......

$11 / 2$ to $2 \mathrm{ft}$. bushy, $\$ 8000$ per thousand.......

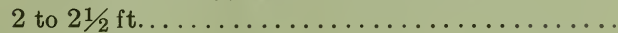

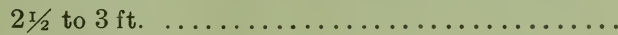

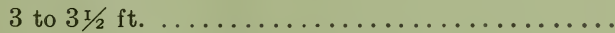

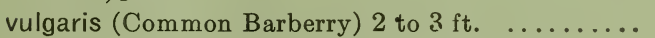

vulg. var. purpurea (Purple-leaved Barberry)

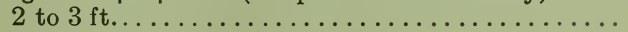

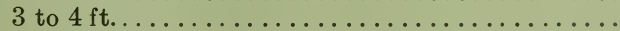

BUDDLEIA variabilis magnifica (Butterfly Bush)

\section{3 yrs.}

CALYCANTHUS floridus 2 to $3 \mathrm{ft}$.

CEANOTHUS americanus 18 to 24 in.

CEPHALANTHUS occidentalis (Button Bush)

2 to $3 \mathrm{ft}$

3 to $4 \mathrm{ft}$

CHIONANTHUS virginica (See under Trees)

CLETHRA alnifolia (Sweet Pepper Bush)

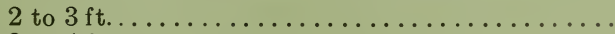

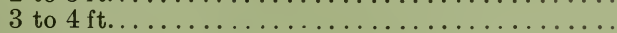

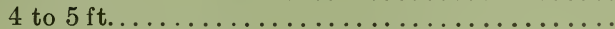

COMPTONIA asplenifolia 18 to 24 in.

2 to $3 \mathrm{ft}$.

CORNUS alternifolia (Blue Dogwood) 3 to $4 \mathrm{ft}$. ....

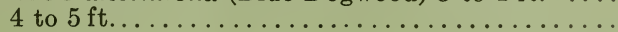

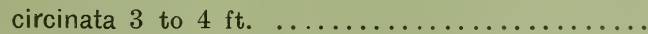

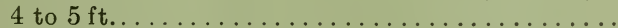

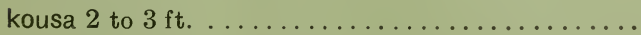

mascula (Cornelian Cherry) 2 to $3 \mathrm{ft}$...........

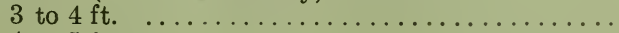

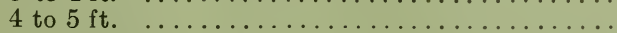

paniculata (Gray Dogwood) 2 to $3 \mathrm{ft} . . . \ldots \ldots$.

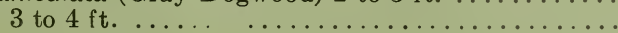

sericea (Silky Cornel) 4 to $5 \mathrm{ft} . \ldots \ldots \ldots \ldots \ldots \ldots$

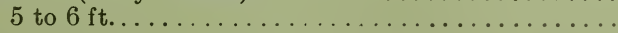

siberica or alba (Red barked Dogwood)

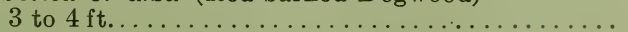

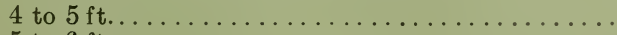

5 to $6 \mathrm{ft}$.

sib. var. elegantissima variegata 3 to $4 \mathrm{ft} . \ldots \ldots$.

4 to $5 \mathrm{ft}$. pyramids

sib. var. spaethi aurea 2 to $3 \mathrm{ft}$.

stolonifera 4 to $5 \mathrm{ft}$.

stol. var. lutea (Yellow-barked Dogwood) 2 to $3 \mathrm{ft}$.

3 to $4 \mathrm{ft}$.
Each

30

35

Per 10

250

20

25

30

300

150

1000

200

250

1500

2000 
COTONEASTER simonsi 2 to $3 \mathrm{ft}$............ 35

CYDONIA japonica (Japan Quince-pink) 18 to 24 in.

2 to $3 \mathrm{ft}$.

3 to $4 \mathrm{ft}$.

jap. var. maulei (Dwarf-yellow orange) 2 to $3 \mathrm{ft} .$.

jap. var. umbilicata (Red) 2 to $3 \mathrm{ft}$.

DEUTZIA candidissima 2 to $3 \mathrm{ft} . \ldots \ldots \ldots \ldots \ldots$

3 to $4 \mathrm{ft}$.

crenata 2 to $3 \mathrm{ft}$.

3 to $4 \mathrm{ft}$.

c. var. Pride of Rochester 2 to $3 \mathrm{ft}$.

3 to $4 \mathrm{ft}$.

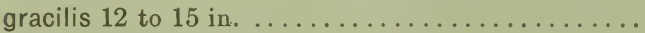

15 to 18 in.

18 to 24 in

g. var. rosea 12 to $15 \mathrm{in}$

lemoinei 18 to 24 in.

2 to $3 \mathrm{ft}$.

watereri 3 to $4 \mathrm{ft}$. bushy

DIERVILLA candida (white) 3 to $4 \mathrm{ft}$

floribunda (red) 2 to $3 \mathrm{ft}$.

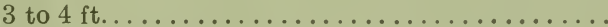

hybrida Eva Rathke (dark red) 18 to 24 in. .....

2 to $3 \mathrm{ft}$.

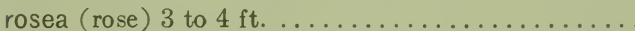

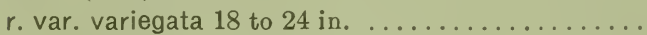

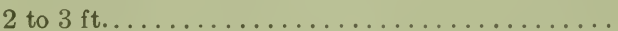

ELEAGNUS longipes 3 to $4 \mathrm{ft}$.

EUONYMUS alata (Cork-barked Euonymus)

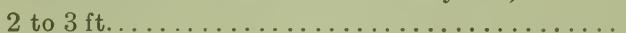

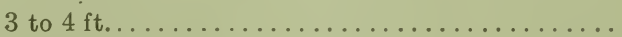

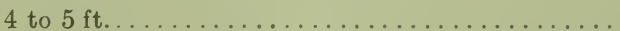

5 to $6 \mathrm{ft}$. specimens

6 to $7 \mathrm{ft}$. specimens

americana var. atropurpurea 4 to $5 \mathrm{ft}$.............

5 to $6 \mathrm{ft}$.

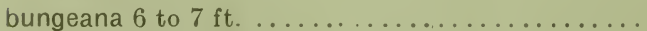

europaea 3 to $4 \mathrm{ft} . \ldots \ldots \ldots \ldots \ldots \ldots \ldots \ldots$. . . . . . . . . . . .

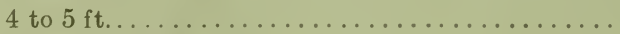

obovata 2 to $3 \mathrm{ft}$.

Desirable for covering rocky banks.

EXOCHORDA grandiflora 2 to $3 \mathrm{ft} . \ldots \ldots \ldots \ldots \ldots$

FORSYTHIA fortunei (Golden Bell) 3 to $4 \mathrm{ft}$. .....

4 to $5 \mathrm{ft}$.

5 to $6 \mathrm{ft} . \ldots \ldots \ldots \ldots \ldots \ldots$

intermedia 3 to $4 \mathrm{ft}$.

4 to $5 \mathrm{ft}$.
Per 10 Per 100

350

$300 \quad 2500$

$120 \quad 1000$

$150 \quad 1200$

$200 \quad 1500$

$200 \quad 1500$

$200 \quad 1500$

$150 \quad 1000$

200

150

180

150

200

150

200

250

1000

1000

1000

1500

1800

25

20

25

25

30

25

30

30

35

30

25

30

35

50

75

125

200

250

30

40

75

30

40

30

160

1200

200

1500

200

1500

250

200

250

250

300

250

200

250

300

2000

400

3500

$600 \quad 5000$

1000

1500

10000

2000

250

350

250

2000.

250

200

1500

160

1200

200

1500

250

1800

160

1200 
FORSYTHIA Continued

Each

suspensa 3 to $4 \mathrm{ft}$.

4 to $5 \mathrm{ft}$.

5 to $6 \mathrm{ft}$

viridissima 3 to $4 \mathrm{ft}$

4 to $5 \mathrm{ft}$.

GENISTA tinctoria 2 to $3 \mathrm{ft}$.

HALESIA carolina (Silver Bell) 3 to $4 \mathrm{ft}$.

HAMAMELIS virginica 2 to $3 \mathrm{ft}$.

HIPPOPHAE rhamnoides (Sea Buckthorn) 2 to $3 \mathrm{ft}$.

3 to $4 \mathrm{ft}$.

\section{HYDRANGEA}

arborescens grandiflora alba (Hills of Snow)

2 to $3 \mathrm{ft}$.

paniculata (Type) 4 to $5 \mathrm{ft} . \ldots \ldots \ldots \ldots \ldots \ldots$

paniculata grandiflora 2 to $3 \mathrm{ft}$.

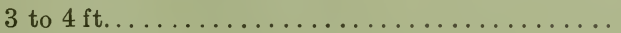

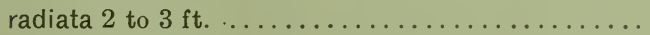

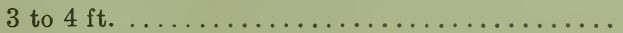

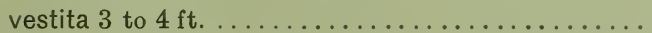

HYPERICUM aureum 2 to $3 \mathrm{ft} . \quad \therefore \ldots \ldots \ldots \ldots$

ILEX verticillata (Black Alder) 2 to $3 \mathrm{ft} . \ldots \ldots \ldots$.

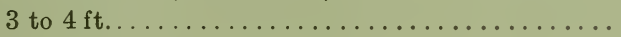

4 to $5 \mathrm{ft}$. bushy $\ldots \ldots \ldots \ldots \ldots \ldots \ldots \ldots \ldots \ldots \ldots \ldots \ldots \ldots$

5 to $6 \mathrm{ft}$. bushy ................................

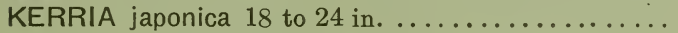

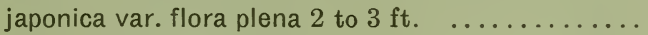
jap. variegata 15 to 18 in.

LIGUSTRUM amurense (Amoor River Privet)

2 to $3 \mathrm{ft}$.

ibota (Chinese Privet) 2 to $3 \mathrm{ft} \ldots \ldots \$ 7000$ per $\mathrm{M}$

3 to $4 \mathrm{ft} . \ldots \ldots \ldots \ldots \ldots \ldots \ldots 900$ per M

4 to $5 \mathrm{ft}$. ............. $\$ 10000$ per M

ibota var. Regelianum (Spreading Form)

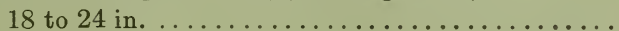

2 to $2 \frac{1}{2} \mathrm{ft}$.

$21 / 2$ to $3 \mathrm{ft}$.

ovalifolium (California Privet)

2 to $3 \mathrm{ft}$.

vulgare 3 to $4 \mathrm{ft}$.

LONICERA fragrantissima 2 to $3 \mathrm{ft}$.

3 to $4 \mathrm{ft}$.

morrowii 3 to $4 \mathrm{ft}$.

morrowii, spreading form 2 to $3 \mathrm{ft}$.

3 to $4 \mathrm{ft}$.

ruprechtiana 3 to $4 \mathrm{ft}$.

standishii 3 to $4 \mathrm{ft}$.

4 to $5 \mathrm{ft}$.
Per 10 Per 100

$25 \quad 200 \quad 1500$

$30 \quad 250 \quad 2000$

$35 \quad 300$

$20 \quad 160 \quad 1200$

$25 \quad 200 \quad 1500$

$20 \quad 160 \quad 1200$

$35 \quad 300$

$40 \quad 350$

$25 \quad 200 \quad 1500$

$30 \quad 250 \quad 2000$

$\begin{array}{llll}30 & 250 & 20 & 00\end{array}$

$30 \quad 250$

$20 \quad 160 \quad 1200$

$25 \quad 200 \quad 1500$

$20 \quad 150 \quad 1000$

$25 \quad 200 \quad 1500$

$20 \quad 150$

$25 \quad 200$

$30 \quad 250 \quad 2000$

$40 \quad 350 \quad 3000$

$\begin{array}{lllll}50 & 4 & 50 & 40 & 00\end{array}$

$75 \quad 600$

$20 \quad 160$

$25 \quad 200$

$25 \quad 200$

1500

20. $150 \quad 1000$

$15 \quad 120 \quad 800$

$20 \quad 150 \quad 1000$

$25 \quad 180 \quad 1200$

$20 \quad 160 \quad 1200$

$25 \quad 200 \quad 1500$

$30 \quad 250 \quad 1800$

$\begin{array}{rr}80 & 500\end{array}$

$20 \quad 160 \quad 1200$

$25 \quad 200 \quad 1200$

$30 \quad 250 \quad 1800$

$25 \quad 180 \quad 1200$

$\begin{array}{llll}20 & 160 & 1200\end{array}$

$25 \quad 200$

$20 \quad 160 \quad 1200$

$\begin{array}{lllll}20 & 160 & 1200\end{array}$

$25 \quad 200 \quad 1500$ 
LONICERA Continued

tatarica (rosea) 3 to $4 \mathrm{ft}$

Each

4 to $5 \mathrm{ft}$.

t. var. albida 3 to $4 \mathrm{ft}$.

t. var. grandiflora alba 2 to $3 \mathrm{ft}$. 3 to $4 \mathrm{ft}$.

t. var. grandiflora rosea 2 to $3 \mathrm{ft}$.

3 to $4 \mathrm{ft}$.

4 to $5 \mathrm{ft}$.

5 to $6 \mathrm{ft}$

t. var. grandiflora rubra 2 to $3 \mathrm{ft}$

3 to $4 \mathrm{ft}$.

MAHONIA aquifolium (See evergreen shrubs)

MYRICA cerifera 12 to 15 in.

15 to 18 in.

18 to $24 \mathrm{in}$.

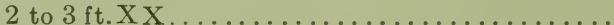

PHILADELPHUS coronarius (Mock Orange) 3 to $4 \mathrm{ft}$. 4 to $5 \mathrm{ft}$.

5 to $6 \mathrm{ft}$. bushy .......... $\$ 15000$ per M

6 to $8 \mathrm{ft}$. bushy .............. $\$ 17500$ per M

c. var. aureus (Golden Syringa) 18 to 24 in.

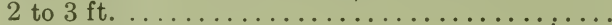

c. var. nanus 2 to $3 \mathrm{ft}$.

grandiflorus 4 to $5 \mathrm{ft}$.

lemoinei 2 to $3 \mathrm{ft}$.

3 to $4 \mathrm{ft}$.

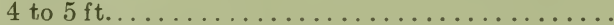

I. var. Avalanche 2 to $3 \mathrm{ft}$.

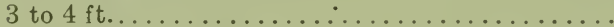

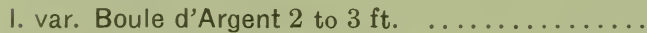

I. var. Bouquet de Blanc 2 to $3 \mathrm{ft}$. 3 to $4 \mathrm{ft}$.

I. var. Conquete 2 to $3 \mathrm{ft}$.

I. var. Dame Blanche (semi-double) 2 to $3 \mathrm{ft} . . . . .$.

I. var. erectus 2 to $3 \mathrm{ft}$.

3 to $4 \mathrm{ft}$.

I. var. Mont Blanc 2 to $3 \mathrm{ft}$. 3 to $4 \mathrm{ft}$.

PRUNUS japonica alba plena (Double White Almond) 2 to $3 \mathrm{ft}$.

3 to $4 \mathrm{ft}$.

j. var. rosea plena (Double Pink Flowering Almond) 2 to $3 \mathrm{ft}$.

3 to $4 \mathrm{ft}$.

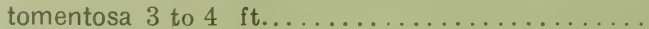

25

30

20

20

25

20

25

30

35

20

25

25

30

35

75

25

30

35

40

35

40

30

25

20

25

30

20

25

30

35

45

30

30

30

35

25

30

30

35

30
35

35

15

20

25

4 to $.5 \mathrm{ft}$.

5 to $6 \mathrm{ft}$.

Per 10

200

Per 100

250

1500

160

1800

150

200

150

200

250

300

160

200

1000

1000

1500

200

250

300

650

200

250

300

350

300

350

250

200

160

200

250

150

200

250

300

400

250

$20 \quad 00$

250

2000

250

300

180

250

250

300

2000

250

300

120

150

800

180

1000

1200

-Prunus tomentosa posesses real merit. It is absolutely hardy, and not subject to San Jose scale. The foliage of itself is a thing of beauty. When it has obtained its growth it will bloom profusely in early Spring, and bear abundance of fruit in early Autumn. The fruit resembles small cherries, is highly ornamental and edible for man as well as birds. 
PTELEA (See under Trees)

Each Per 10 Per 100

PYRUS (See Aronia)

RHAMNUS cathartica (Buckthorn) 3 to $4 \mathrm{ft} . \ldots \ldots .20 \quad 20 \quad 150$

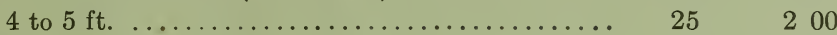

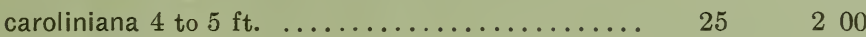

1500

5 to $6 \mathrm{ft}$

30

250

1800

RHODORA canadense (See Azalea canadensis)

RHODOTYPOS kerrioides 2 to $3 \mathrm{ft}$........... 20

3 to $4 \mathrm{ft} . \ldots \ldots \ldots \ldots \ldots \ldots \ldots \ldots \ldots \ldots \ldots \ldots \ldots \ldots \ldots \ldots \ldots \ldots \ldots \ldots \ldots \ldots$

RHUS canadensis syn. aromatica (Fragrant Sumac)

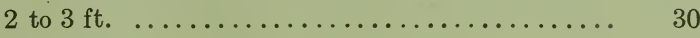

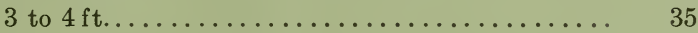

cotinus (Purple Fringe) 2 to $3 \mathrm{ft} . \ldots \ldots \ldots \ldots \ldots . \ldots$

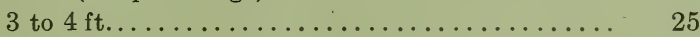

200

1500

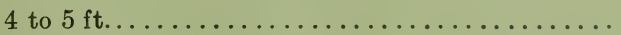

$250 \quad 2000$

glabra (Smooth Sumac) 2 to $3 \mathrm{ft}$.

3 to $4 \mathrm{ft}$. .

typhina (Staghorn Sumac) 2 to $3 \mathrm{ft}$

ROSA blanda 2 to $3 \mathrm{ft} . \ldots \ldots \ldots \ldots \ldots \ldots \ldots \ldots$

carolina (Swamp Rose) 18 to 24 in.

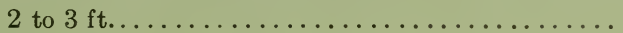

lucida 12 to $18 \mathrm{in.}$.

18 to 24 in.

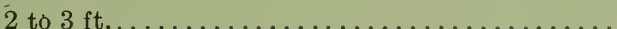

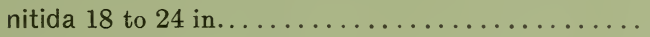

rubiginosa (Sweet Briar Rose) 2 to $3 \mathrm{ft} . \ldots \ldots \ldots$

3 to $4 \mathrm{ft}$.

rubrifolia (Red-leaved Rose)

2 to $3 \mathrm{ft}$. strong plants .................. 20

$150 \quad 1000$

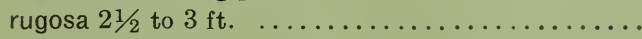

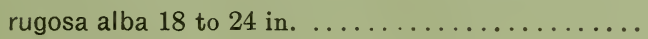

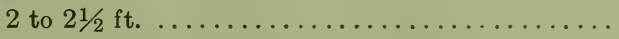

setigera (Prairie Rose) 2 to $3 \mathrm{ft}$. . $\$ \$ 9000$ per $M$

3 to $4 \mathrm{ft} . \ldots \ldots \ldots \ldots \ldots \ldots \$ 10000$ per $\mathrm{M}$

Wichuraiana (Memorial Rose) 3 yrs............

RUBUS odoratus 3 to $4 \mathrm{ft} \ldots \ldots \ldots \ldots \ldots \ldots \ldots$

SAMBUCUS canadensis (Common Elder)

2 to $3 \mathrm{ft}$. 
SPIRAEA arguta 2 to $3 \mathrm{ft}$. bushy

Each

3 to $4 \mathrm{ft}$. bushy..................... 30

blumeii (Pink) 2 to $3 \mathrm{ft} . \ldots \ldots \ldots \ldots \ldots \ldots \ldots . \ldots \ldots$

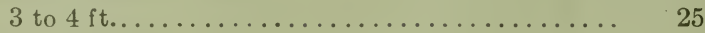

bumalda 18 to 24 in..................... 20

2 to $3 \mathrm{ft}$.

b. var. Anthony Waterer

18 to 24 in.

2 to $3 \mathrm{ft}$.

callosa 3 to $4 \mathrm{ft}$

c. var. alba 18 to 24 in.

opulifolia (Nine Bark) 3 to $4 \mathrm{ft}$.

4 to $5 \mathrm{ft}$.

o. var. aurea (Golden Spiraea) 3 to $4 \mathrm{ft}$.

4 to $5 \mathrm{ft}$. .

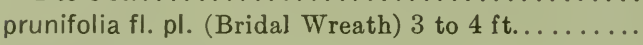

salicifolia 3 to $4 \mathrm{ft} . \ldots \ldots \ldots \ldots \ldots \ldots \ldots \ldots \ldots \ldots$

thunbergii $2 \frac{1}{2}$ to $3 \mathrm{ft}$.

3 to $4 \mathrm{ft}$.

tomentosa 2 to $3 \mathrm{ft} . \ldots \ldots \ldots \ldots \ldots \ldots \ldots \ldots$

3 to $4 \mathrm{ft} . \ldots \ldots \ldots \ldots \ldots \ldots \ldots \ldots \ldots \ldots \ldots \ldots \ldots . \ldots \ldots$

ulmifolia (white, very fine) 3 to $4 \mathrm{ft} . \ldots \ldots \ldots \ldots$

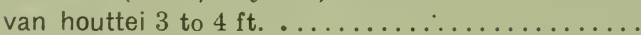

4 to $5 \mathrm{ft}$.

STEPHANANDRA flexuosa 2 to $3 \mathrm{ft}$.

SYMPHORICARPOS racemosus (Snowberry)

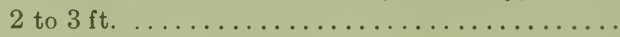

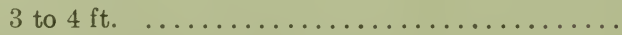

vulgaris (Indian Currant) 2 to $3 \mathrm{ft} . \ldots \ldots \ldots \ldots$

3 to $4 \mathrm{ft}$.

SYRINGA josikaea 2 to $3 \mathrm{ft}$.

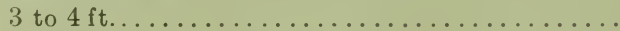

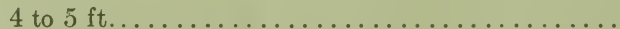

persica (Persian Lilac) 3 to $4 \mathrm{ft}$. ..............

4 to $5 \mathrm{ft}$.

pubescens 5 to $6 \mathrm{ft}$.

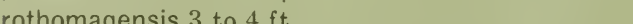

4 to $5 \mathrm{ft}$.

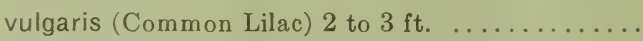

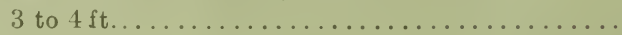

4 to $5 \mathrm{ft}$.

vulgaris alba (Common White Lilac) 2 to $3 \mathrm{ft}$. ...

3 to $4 \mathrm{ft}$.

4 to $5 \mathrm{ft}$. bushy

5 to $6 \mathrm{ft}$. bushy

6 to $8 \mathrm{ft}$. bushy

Abel Carriere (Large double blue) 18 to 24 in.....

2 to $3 \mathrm{ft}$.....
Per 10

200

250

160

200

150

200

25

30

35

25

25

20

25

20

25

30

20

25

30

20

25

30

25

30

25

250

300

200

200

150

200

150

200

250

150

200

250

150

200

250

200

250

200

1000

1500

1000

1000

1500

1800

1000

1200

1500

2000

1500

20

25

160

1200

200

150

1500 •

20

25

200

1000

30

35

40

250

300

350

35

300

350

40

35

300

40

25

30

40

20

25

40

75

100

30

350

200

250

350

150

200

350

600

800

250

300
1500

2000

3000

1200

3000

4500

6000 
Alphonse Lavelle (Double deep lilac) 18 to 24 in... $30 \quad 250$

2 to $3 \mathrm{ft}$.

Belle de Nancy (Double brilliant satin rose)

18 to 24 in. . . . . . . . . . . . . . . . 35

3 to $4 \mathrm{ft}$

Charles Baltet (Double rosy lilac) 18 to 24 in......

Charles Joly (Double deep red) 18 to 24 in....... 35

Charles $X$. (Single reddish purple) 2 to $3 \mathrm{ft}$......

Edward Andre (Double clear rose) 18 to 24 in. .....

Frau Bertha Dammann (Single pure white) 2 to $3 \mathrm{ft}$. $\quad 35$

Marie LeGray (Single creamy white; dwarf)

18 to 24 in........................ 30

Michael Buchner(Double pale lilac; dwarf) 2 to $3 \mathrm{ft}$.

Mme. Abel Chatenay (Double pure white) 18 to 24 in. 30

Pres. Carnot (Double lavender; white center)

18 to 24 in 
SYRINGA Continued

Rubra de Marley (Single rosy purple) 2 to $3 \mathrm{ft}$... 3 to $4 \mathrm{ft}$

Sanguinea Rubra Major (Red) 2 to $3 \mathrm{ft}$ 3 to $4 \mathrm{ft}$.

Souv. de L. Spaeth (Single dark red) 18 to 24 in. 2 to $3 \mathrm{ft}$. 3 to $4 \mathrm{ft}$.

Wm. Robinson (Double pink) 2 to $3 \mathrm{ft}$. 3 to $4 \mathrm{ft}$.

TAMARIX africana 3 to $4 \mathrm{ft}$.

VACCINIUM corymbosum (High Bush Blueberry).

2 to $3 \mathrm{ft}$. 3 to $4 \mathrm{ft}$.

VIBURNUM cassinodes 2 to $3 \mathrm{ft}$. dentatum 3 to $4 \mathrm{ft}$.

4 to $5 \mathrm{ft}$.

5 to $6 \mathrm{ft}$

Iantana 2 to $3 \mathrm{ft}$.

3 to $4 \mathrm{ft}$.

lentago 2 to $3 \mathrm{ft}$.

3 to $4 \mathrm{ft}$

4 to $5 \mathrm{ft}$.

opulus (High Bush Cranberry) 3 to $4 \mathrm{ft}$.

4 to $5 \mathrm{ft}$.

5 to $6 \mathrm{ft}$

opulus sterilis (Common Snowball) 2 to $3 \mathrm{ft}$.

tomentosum 2 to $3 \mathrm{ft}$.

t. var. plicatum (Japanese Snowball) 2 to $3 \mathrm{ft}$..... 3 to $4 \mathrm{ft}$.

WEIGELA See Diervilla

XANTHORRHIZA apiifolia 6 to 12 in
Each

35

45

35

50

30

35

50

35

50

20

150

60

75

30

25

30

35

25

30

30

35

40

25

30

35

25

30

30

35

550

$50 \quad 00$

700

250

2200

200

1500

250

2000

300

2500

200

250

250

2000

300

2500

$350 \quad 3000$

200

1500

250

2000

300

2500

200

250

2000

250

$300 \quad 2500$

20 


\section{ROSES}

Our roses are grown in the United States of America, and are far superior to foreign-grown stock. All the roses we offer for sale are strong two year field-grown plants.

\section{HARDY JUNE ROSES}

Hybrid Perpetual and Other Varieties.

Crested Moss Deep pink................ 30

Fisher Holmes Large brilliant crimson......... 30

Frau Karl Druschki Large pure white ......... 35

General Jacqueminot Brilliant crimson ......... 30

Hugh Dickson Brilliant crimson, fragrant....... 30

Louis Van Houtte Red, fragrant ............ 30

Per 10 Per 100

Margaret Dickson Large flesh pink...........

Mme. Gabriel Luizet Silvery pink, fragrant .....

M. P. Wilder Large, carmine, fragrant .........

Mrs. John Laing Soft pink, large, fragrant......

Paul Neyron Deep pink, large. fragrant... .....

Persian Yellow Small, bright yellow ............

Prince Camille de Rohan Large, deep crimson ...

Ulrich Brunner Brilliant cherry-red ...........

30

250

35300

2500

$250 \quad 2200$

250

250

$30 \quad 250$

$35 \quad 300$

$30 \quad 250$

$30 \quad 250$

30

$30 \quad 250$

$35-300$

$35 \quad 300$

2500

2500

\section{EVER BLOOMING ROSES}

Baby Dorothy Perkins Pink Baby Rambler ..... $35 \quad 300$

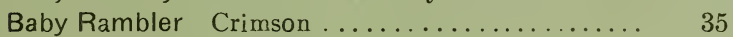

Baby Rambler White .................. 35

General MacArthur Large, sweet, crimson-scarlet. $\quad 35 \quad 320$

Gruss an Teplitz Double deep red, fragrant ...... $\quad 30 \quad 250$

$300 \quad 2500$

Jessie Bright cherry-red, dwarf ............ 35

Jubilee Large, velvety crimfon, fragrant....... 30

300

2200

250

Kaiserin Augusta Victoria Cream-white, fragrant..

350

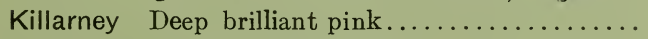

La France Silvery pink, fragrant ........... 30

$\begin{array}{llll}35 & 3 & 00 \\ 30 & 2 & 50 & 1\end{array} 2200$

Mme. Caroline Testout Large, double pink...... 35

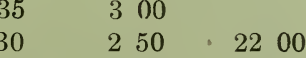

2500

Mme. Leon Pain Salmon pink, orange center.....

300

3200

$35 \quad 300 \quad 2700$

Rayon d'Or Large, yellow................ 45

\section{HARDY RAMBLERS}

\begin{tabular}{|c|c|c|c|}
\hline & $\mathrm{ch}$ & Per 10 & Per 100 \\
\hline Crimson Rambler & 30 & 250 & 2200 \\
\hline Pink Rambler ... & 30 & 250 & \\
\hline 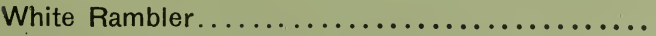 & 30 & & \\
\hline 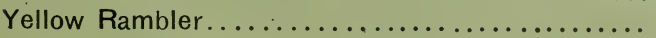 & 30 & 250 & \\
\hline
\end{tabular}




\section{CLIMING AND TRAILING ROSES}

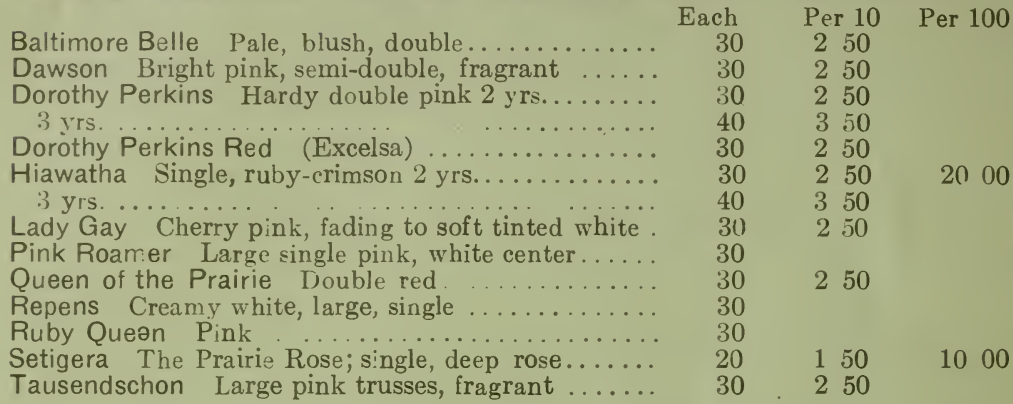

\section{ROSA RUGOSA HYBRIDS}

Conradi Ferd. Meyer Silvery-rose, large, double

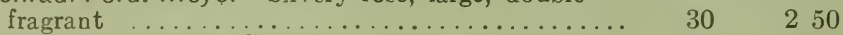
Roseraie de L'Hay Crimson ............... $30 \quad 250$

\section{WICHURAIANA HYBRIDS}

Gardenia Yellow opening cream-white......... $30 \quad 250$ South Orange Perfection Soft blush pink, ............ $30 \quad 250$ Universal Favorite Large double pink clusters, fragrant $30 \quad 250$

\section{VINES AND CLIMBERS}

ACTINIDIA arguta 2 yrs. .................. 25

AKEBIA quinata 2 yrs.

AMPELOPSIS quinquefolia (Virginia Creeper) 3 yrs. quinq. var. engelmanni 3 yrs.

ARISTOLOCHIA sipho (Dutchman's Pipe Vine)

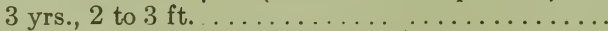
BIGNONIA radicans (Trumpet Vine) 2 yrs. ........... CELASTRUS articulatus (Japanese Bittersweet) 4 yrs. $\ldots \ldots \ldots \ldots \ldots \ldots \ldots \ldots \ldots \ldots \ldots \ldots \ldots \ldots \ldots \ldots \ldots \ldots \ldots$ 4 yrs.

CLEMATIS Duchess of Edinburg 2 yrs. field-grown

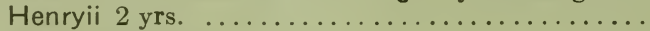

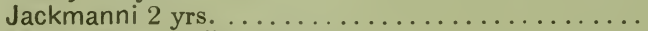

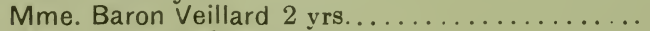

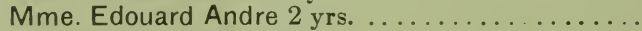

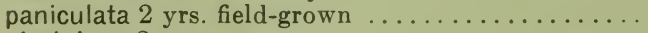

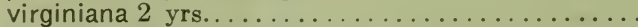

EUONYMUS radicans (See under Evergreen Shrubs)

HEDERA helix (English Ivy) 2 in. pots, 2 to $3 \mathrm{ft}$. tops

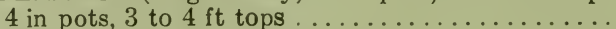

LONICERA (Honeysuckle)

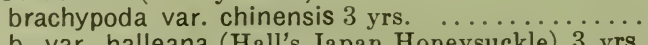
b. var. halleana (Hall's Japan Honeysuckle) 3 yrs. LYCIUM barbarum 3 yrs. chinensis 3 yrs.....

TECOMA See Bigonia

WISTARIA chinensis (Chinese Wistaria) blue

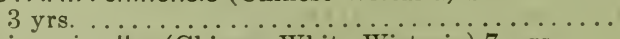
chinensis alba (Chinese White Wistaria) 7 yrs....
Each

25

20

20 


\section{FRUIT TREES}

APPLES, $3 / 4$ in. and up

Each Per 10

Per 100

Summer Varieties,

Red Astrachan, Sweet Bough, William's Favorite,

Yellow Transparent.

Autumn Varieties

$\checkmark$ Fameuse, Gravenstein, Maiden Blush.

Winter Varieties,

Baldwin, Delicious, Gano, Hubbardston, Jonathan, King, McIntosh, Northern Spy, R. I. Greening, 'Roxbury Russett, Stayman's Winesap, Talman Sweet, Wealthy.

DWARF APPLES

Summer Varieties, Early Harvest, Fameuse, Red

Astrachan, William's Favorite, Yellow Transparent.

Autumn Varieties, Gravenstein.,

Winter Varieties Baldwin, McIntosh Red, R. I.

Greening.

CRAB APPLES 5 to $7 \mathrm{ft}$.

Hyslop, Martha, Transcendent.

STANDARD PEARS, $11-16$ in. and up

Anjou, Bartlett, Clapp's Favorite, Duchess,

Flemish Beauty, Lawrence, 'Seckel, Sheldon,

Worden Seckel.

Beurre Bosc 11-16 in. and up.

60

500

4500

DWARF PEARS, $5 / 8$ in. and up.

Bartlett, Clapp's Favorite,-Duchess, Seckel.

CHERRIES, $3 / 4$ in. and up

Black Tartarian, Early Richmond, Gov. Wood,

$\checkmark$ Montmorency, Napoleon, Windsor, Yellow Spanish. 
PLUMS, $3 / 4$ in. and up

Each Per 10 Per 100

Abundance, Bradshaw, Burbank; Green Gage, Lombard, October Purple, Red June, Reine Claude, Satsuma, Shropshire Damson, Yellow Egg.

PEACHES, $5 / 8$ in. and up

Carman, Champion, Crawford Early, Crawford Late, Elberta, Fitzgerald, Mt. Rose, Old Mixon, Stump.

QUINCE, 4 to $5 \mathrm{ft}$.

Orange, Rea's Mammoth.

\section{SMALL FRUITS}

GRAPES, 2 yrs.

Agawam, Brighton, Concord, Delaware, Moore's

Early, Niagara, Pocklington, Salem, Worden.

Green Mountain, Campbell's Early

Cumberland, Cuthbert, Golden Quee, St, Regis.

Eldorado, Rathbun. 


\section{TRANSPORTATION}

In the present transportation crisis it is well to analyze the true situation. Owing to the shipments of food and munitions to Europe, the amount of goods to be transported over the railroads has increased by more than 50 per cent.

But please bear in mind that this increase is almost entirely in an easterly direction. About 75 per cent of the total shipping at the present time is toward the Atlantic seaports. Traffic in the westerly direction has increased very slightly if at all.

For the above reasons it is difficult to ship into New England, but very easy to ship from New England in a westerly direction. Moreover, by combining orders going to any given locality and making full carload shipments, we can assure our customers of very prompt delivery to points outside New England.

Don't let transportation conditions keep you from ordering your share of Framingham Quality Nursery Stock. Give us the business and leave the delivery to us.

Owing to our location at one of the best shipping centers in New England, we can assure our customers in New England of prompt delivery. We are prepared to ship nursery stock by Motor Truck to distances of one hundred miles-and even longer.

The cost of this delivery will be less than less-carload freight rates, for stock shipped by motor truck does not require packinghence no packing charges.

We repeat-give us the business and you may be sure we will look out for the prompt delivery of your orders. 


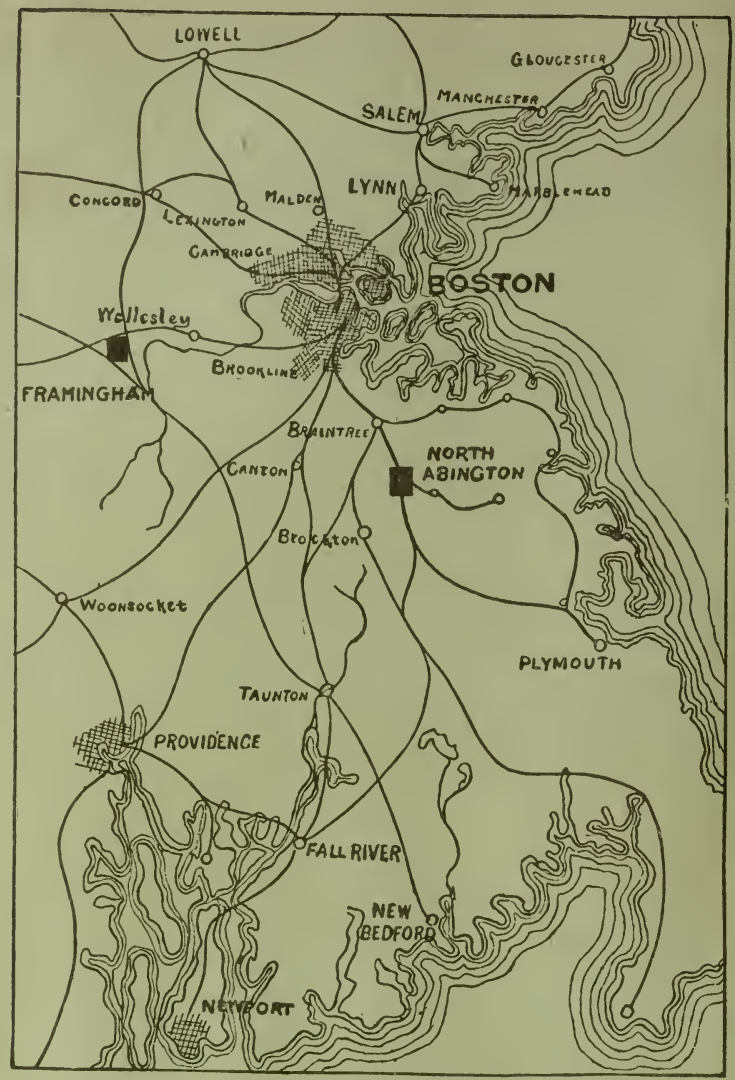

OUR LOCATION

FRAMINGHAM NURSERIES are located in Framingham. Mass, about 20 miles from Boston and from Worcester, on the main line of the Boston \& A1bany division of the New York Central R. R. Also on the New Haven R. R.

Neariy all the trains to Boston from the West and from New York by the way of Springfield stop here. Trains leave the South Station, Boston, for Framingham every fifteen or twenty minutes.

We are situated about two miles from the Framingham station. We are reached from that point by the Boston-bound cars of the Boston \& Worcester Street Railway Co. Ask the conductor for the FRAMINGHAM NURSERIES STOP. Phone us from the Framingham station and we will meet you there.

From Boston we may also be reached by any local car of the Boston \& Worcester Street Railway Co. which goes as far as Framingham Junction. These cars leave from Park Square. Ask the conductor for our stop. From Worcester, any Boston-bound local car will leave you at our stop

By motor from the West, turn from the New York \& Boston Motor Road to the right at East Sudbury and continue for about three miles. From Boston take Commonwealth Ave. to its end, then South St. for about seven miles. You can't help seeing our swinging sign. 